\title{
Modelling $\mathrm{N}_{2}$ fixation related to Trichodesmium sp.: driving processes and impacts on primary production in the tropical Pacific Ocean
}

\author{
Cyril Dutheil ${ }^{1,2}$, Olivier Aumont ${ }^{2}$, Thomas Gorguès ${ }^{3}$, Anne Lorrain ${ }^{4}$, Sophie Bonnet ${ }^{5}$, Martine Rodier ${ }^{6}$, \\ Cécile Dupouy $^{1,5}$, Takuhei Shiozaki ${ }^{7}$, and Christophe Menkes ${ }^{1,2}$ \\ ${ }^{1}$ Centre IRD, Nouméa, New Caledonia \\ ${ }^{2}$ LOCEAN Laboratory, IPSL, Sorbonne Universités (UPMC, Univ Paris 06)-CNRS-IRD-MNHN, Paris, France \\ ${ }^{3}$ Laboratoire d'Océanographie Physique et Spatiale (LOPS), Univ. Brest-CNRS-Ifremer-IRD, Plouzané, France \\ ${ }^{4}$ LEMAR, UMR 6539, UBO-CNRS-Ifremer-IRD, IUEM, Plouzané, France \\ ${ }^{5}$ Aix Marseille Université, CNRS/INSU, Université de Toulon, IRD, Mediterranean Institute of Oceanography (MIO) \\ UM 110, 13288, Marseille, France \\ ${ }^{6}$ Environnement Insulaire Océanien (EIO), UMR 241 (Univ. de Polynésie Française, IRD, ILM, IFREMER), \\ Tahiti, French Polynesia \\ ${ }^{7}$ Research and Development Center for Global Change, Japan Agency for Marine-Earth Science \\ and Technology, Yokosuka, Japan
}

Correspondence: Cyril Dutheil (cyril.dutheil@ird.fr)

Received: 24 December 2017 - Discussion started: 15 January 2018

Revised: 29 May 2018 - Accepted: 3 July 2018 - Published: 18 July 2018

\begin{abstract}
Dinitrogen fixation is now recognized as one of the major sources of bio-available nitrogen in the ocean. Thus, $\mathrm{N}_{2}$ fixation sustains a significant part of the global primary production by supplying the most common limiting nutrient for phytoplankton growth. The "Oligotrophy to UlTra-oligotrophy PACific Experiment" (OUTPACE) improved the data coverage of the western tropical South $\mathrm{Pa}$ cific, an area recently recognized as a hotspot of $\mathrm{N}_{2}$ fixation. This new development leads us to develop and test an explicit $\mathrm{N}_{2}$ fixation formulation based on the Trichodesmium physiology (the most studied nitrogen fixer) within a 3-D coupled dynamical-biogeochemical model (ROMS-PISCES). We performed a climatological numerical simulation that is able to reproduce the main physical (e.g. sea surface temperature) and biogeochemical patterns (nutrient and chlorophyll concentrations, as well as $\mathrm{N}_{2}$ fixation) in the tropical Pacific. This simulation displayed a Trichodesmium regional distribution that extends from $150^{\circ} \mathrm{E}$ to $120^{\circ} \mathrm{W}$ in the south tropical Pacific, and from $120^{\circ} \mathrm{E}$ to $140^{\circ} \mathrm{W}$ in the north tropical Pacific. The local simulated maximuma were found around islands (Hawaii, Fiji, Samoa, New Caledonia, Vanuatu). We assessed that $15 \%$ of the total primary produc-
\end{abstract}

tion may be due to Trichodesmium in the low-nutrient lowchlorophyll regions (LNLC) of the tropical Pacific. Comparison between our explicit and the often used (in biogeochemical models) implicit parameterization of $\mathrm{N}_{2}$ fixation showed that the latter leads to an underestimation of $\mathrm{N}_{2}$ fixation rates by about $25 \%$ in LNLC regions. Finally, we established that iron fluxes from island sediments control the spatial distribution of Trichodesmium biomasses in the western tropical South Pacific. Note, this last result does not take into account the iron supply from rivers and hydrothermal sources, which may well be of importance in a region known for its strong precipitation rates and volcanic activity.

\section{Introduction}

Nitrogen is known to be the most common limiting nutrient for phytoplankton growth in the modern world ocean (Moore et al., 2013), especially in the low-nutrient low-chlorophyll (LNLC) ecosystems (Arrigo, 2005; Gruber, 2005). Characterizing the processes governing nitrogen sources and sinks 
to and from the ocean is therefore central to understanding oceanic production, organic matter export, and food-web structure. Atmospheric dinitrogen $\left(\mathrm{N}_{2}\right)$ dissolved in seawater is by far the dominant form of $\mathrm{N}$ present in the ocean, i.e. the $\mathrm{N}_{2}$ : $\mathrm{NO}_{3}^{-}$ratio typically exceeds 100 in surface waters. However, most phytoplankton species cannot assimilate $\mathrm{N}_{2}$, and only grow using reactive forms of nitrogen such as nitrate, ammonium, and dissolved organic compounds. Some planktonic prokaryotic microorganisms, called "diazotrophs", use an enzyme, the nitrogenase, to fix $\mathrm{N}_{2}$ and convert it into ammonia $\left(\mathrm{NH}_{3}\right)$ and ultimately ammonium $\left(\mathrm{NH}_{4}^{+}\right)$. At the global scale, they provide the major external source of reactive nitrogen to the ocean (Gruber, 2008), and support up to $50 \%$ of new production in tropical and subtropical (LNLC) regions (Bonnet et al., 2009; Capone, 1997; Deutsch et al., 2007; Karl et al., 1997; Moutin et al., 2008; Raimbault and Garcia, 2008). These organisms are physiologically and taxonomically diverse including cyanobacteria, bacteria, and archaea (Zehr and Bombar, 2015; Delmont et al., 2018).

Autotrophic diazotrophs have been far more intensively studied than heterotrophic diazotrophs, whose contribution to global $\mathrm{N}_{2}$ fixation remains unclear (Turk-Kubo et al., 2014; Bombar et al., 2016; Moisander et al., 2017). Autotrophic diazotrophs have been characterized both in the field and through laboratory experiments and their physiology is consequently better known (Bergman et al., 2013; Küpper et al., 2008; Mulholland and Capone, 2001, 2000; Ohki et al., 1992; Ramamurthy and Krishnamurthy, 1967; Rubin et al., 2011). Cyanobacterial (autotrophic) diazotrophs are composed of three main groups: (1) the filamentous diazotrophs including the colonial, non-heterocyst-forming Trichodesmium, (2) the heterocyst-forming symbionts associated with diatoms (diatom-diazotroph associations; DDAs), and (3) the unicellular cyanobacterial diazotrophs (UCYN, phylogeneticaly divided into three groups: UCYN-A, -B, and -C). It has been established that autotrophic diazotroph growth rates are typically 1 order of magnitude lower than those of non-diazotrophs (Breitbarth et al., 2008; Falcón et al., 2005; Goebel et al., 2008; LaRoche and Breitbarth, 2005). This can be related to the high energetic demand (Postgate, 1982) required to convert $\mathrm{N}_{2}$ to $\mathrm{NH}_{3}$ as compared to that necessary to assimilate nitrate or ammonia. This low growth rate (compared to other phytoplankton species) mainly constrains their ecological niches to nitrate-poor regions, where they can be competitive. Moreover, their geographical distribution is constrained by nutrient availability in the photic layer (mainly iron and phosphate; BermanFrank, 2001; Bonnet et al., 2009; Mills et al., 2004; Moutin et al., 2005, 2008; Rubin et al., 2011; Rueter, 1988) and temperature (Staal et al., 2003). Trichodesmium sp. are present only in water where the temperature is above $20^{\circ} \mathrm{C}$ (Capone, 1997; LaRoche and Breitbarth, 2005; Montoya et al., 2004), while some UCYN can be found in colder and deeper waters (Bonnet et al., 2015; Church et al., 2005; Moisander et al., 2010).
The spatial distribution and rates of $\mathrm{N}_{2}$ fixation have been inferred at the global scale using several tools. Deutsch et al. (2007) have introduced the tracer $\mathrm{P}^{*}$ which represents the excess of $\mathrm{P}$ relative to the standard $\mathrm{N}$ quota. A decrease in this tracer is then interpreted as $\mathrm{N}_{2}$ fixation, since $\mathrm{N}_{2}$ fixation extracts $\mathrm{PO}_{4}$ alone. More recently, Luo et al. (2014) developed a multiple linear regression that relates $\mathrm{N}_{2}$ fixation from the MAREDAT database (Luo et al., 2012) to environmental conditions (nutrients; sea surface temperature, SST; irradiance; mixed layer depth (MLD), etc.) in order to build a statistical model for global $\mathrm{N}_{2}$ fixation distribution.

Numerical models have also been used as they allow us to overcome the scarcity of observations that may limit the implementation of the two previous approaches (Aumont et al., 2015; Bissett et al., 1999; Dutkiewicz et al., 2012; Krishnamurthy et al., 2009; Monteiro et al., 2011; Moore et al., 2006, 2013; Tagliabue et al., 2008). They can notably be used to investigate the spatial and temporal variability in dinitrogen fixation and to study its controlling environmental factors. In these models, $\mathrm{N}_{2}$ fixation has been implemented in various ways. Some models use implicit parameterizations (Bissett et al., 1999; Maier-Reimer et al., 2005; Assmann et al., 2010; Aumont et al., 2015) to derive $\mathrm{N}_{2}$ fixation from environmental conditions (mainly nitrate, phosphate, and iron concentrations; temperature; and light) without explicitly simulating any nitrogen fixing organisms. Alternatively, other models rely on the explicit descriptions of diazotrophs (Moore et al., 2004; Dunne et al., 2013) that have mainly been developed from the knowledge derived from laboratory experiments focused on Trichodesmium sp. (Fennel et al., 2001; Hood et al., 2001; Moore et al., 2001). Noticeably, several modelling studies have been especially focused on the role of iron in controlling the distribution of diazotrophs and $\mathrm{N}_{2}$ fixation (Krishnamurthy et al., 2009; Moore et al., 2004, 2006; Tagliabue et al., 2008). Indeed, a realistic representation of marine iron concentrations has been stressed as a key factor to adequately simulate the habitat of diazotrophs (Monteiro et al., 2011; Dutkiewicz et al., 2012).

Moreover, among the full set of studies focusing on the spatial distribution of $\mathrm{N}_{2}$ fixation, some studies (Berthelot et al., 2017; Bonnet et al., 2009, 2015; Garcia et al., 2007; Shiozaki et al., 2014) based on oceanographic campaigns have reported high $\mathrm{N}_{2}$ fixation rates in the western tropical South Pacific (WTSP), which has been recently identified as a globally important hotspot of $\mathrm{N}_{2}$ fixation with rates $>$ $600 \mu \mathrm{mol} \mathrm{N} \mathrm{m}{ }^{-2} \mathrm{~d}^{-1}$ (Bonnet et al., 2017). Very high abundances of Trichodesmium have been historically reported in this region (Dupouy et al., 2000, 2011; Moisander et al., 2008; Neveux et al., 2006; Shiozaki et al., 2014; Stenegren et al., 2018) and have recently been identified as the major contributor to $\mathrm{N}_{2}$ fixation in this region (Berthelot et al., 2017; Bonnet et al., 2018). However, the reasons for such an ecological success of diazotrophs in this region are still poorly understood. 
In this study, we aim at bringing new insights into this known, but poorly understood, " $\mathrm{N}_{2}$ fixation hotspot". This study aims to understand the spatial and temporal distribution (i.e. seasonal variability) of Trichodesmium and to evaluate the potential impact of Trichodesmium fixers on the biogeochemical conditions of the WTSP. We will specifically address the following overarching questions: (i) what are the mechanisms that structure the Trichodesmium distribution in the WTSP, particularly around the southwest Pacific islands, and (ii) what is the biogeochemical impact of $\mathrm{N}_{2}$ fixation in this region? Note, this study also takes advantage of the sampling done during the "Oligotrophy to UlTra-oligotrophy PACific Experiment” (OUTPACE), which nicely complements the data coverage in the southwest Pacific, and allows a better characterization of the processes responsible for the spatial and seasonal variability in $\mathrm{N}_{2}$ fixation.

To fulfill our objectives, we have implemented an explicit representation of the nitrogen fixers, based on the Trichodesmium physiology, in a biogeochemical model. The first section of this study describes the experimental design and the observations used in our study, while the second part of the paper provides a validation of our reference simulation with an analysis of the Trichodesmium compartment and its impacts on the biogeochemical conditions of the tropical $\mathrm{Pa}$ cific. In the discussion, the impact of iron from island sediment on dinitrogen fixation is considered as well as the added value of an explicit dinitrogen fixer compartment rather than a simpler implicit representation of $\mathrm{N}_{2}$ fixation. Finally, implications for and limits of our modelling exercise are detailed in the conclusion.

\section{Methods}

\subsection{Coupled dynamical-biogeochemical model (ROMS-PISCES)}

\subsubsection{ROMS}

In this study, we used a coupled dynamical-biogeochemical framework based on the regional ocean dynamical model ROMS (Regional Oceanic Modeling System, (Shchepetkin and McWilliams, 2005) and a new version of biogeochemical model PISCES (Pelagic Interactions Scheme for Carbon and Ecosystem Studies). The ocean model configuration is based on the ROMS-AGRIF (Penven et al., 2006) computer code and covers the tropical Pacific region $\left(33^{\circ} \mathrm{S}-\right.$ $\left.33^{\circ} \mathrm{N}, 110^{\circ} \mathrm{E}-90^{\circ} \mathrm{W}\right)$. It has 41 terrain-following vertical levels with $2-5 \mathrm{~m}$ vertical resolution in the top $50 \mathrm{~m}$ of the water column, then $10-20 \mathrm{~m}$ resolution in the thermocline and 200-1000 $\mathrm{m}$ resolution in the deep ocean. The horizontal resolution is $1^{\circ}$. The turbulent vertical mixing parameterization is based on the non-local $\mathrm{K}$ profile parameterization (KPP) of Large et al. (1994). Open boundary conditions are treated using a mixed active/passive scheme (Marchesiello et al., 2001). This scheme is used to force our regional configuration with monthly climatological large-scale boundary conditions from a $0.5^{\circ}$ ORCA global ocean simulation (details available in Kessler and Gourdeau, 2007), while allowing anomalies to radiate out of the domain. The use of similar ROMS configurations (e.g. vertical resolution, mixed active/passive scheme, turbulent vertical mixing parameterization) in the WTSP is largely validated through studies demonstrating skills in simulating both the surface (Jullien et al., 2012, 2014; Marchesiello et al., 2010) and subsurface ocean circulation (Couvelard et al., 2008).

To compute the momentum and fresh water and/or heat fluxes, we also use a climatological forcing strategy. Indeed, documenting the interannual to decadal variability is beyond the scope of our study, which justifies using climatological forcing fields. A monthly climatology of the momentum forcing is computed from the 1993-2013 period of the ERS1-2 scatterometer stress (http://cersat.ifremer.fr/oceanography-from-space/ our-domains-of-research/air-sea-interaction/ers-ami-wind, last access: 12 July 2018). Indeed, the ERS-derived forcing has been shown to produce adequate simulations of the Pacific Ocean dynamics (e.g. Cravatte et al., 2007). A monthly climatology at $0.5^{\circ}$ resolution computed from the Comprehensive Ocean-Atmosphere Data Set (COADS; Da Silva et al., 1994) is used for heat and fresh water forcing. In our set-up, ROMS also forces on line a biogeochemical model using a WENO5 advection scheme (i.e. five order weighted essentially non-oscillatory scheme; Shchepetkin and McWilliams, 1998). After a 1-year spin-up, we stored 1 -day averaged outputs for analysis.

\subsubsection{PISCES}

In this study, we use a quota version of the standard PISCES model (Aumont and Bopp, 2006; Aumont et al., 2015), which simulates the marine biological productivity and the biogeochemical cycles of carbon and the main nutrients $(\mathrm{P}$, $\mathrm{N}, \mathrm{Si}, \mathrm{Fe}$ ). This modified model, called PISCES-QUOTA, is extensively described in Kwiatkowski et al. (2018). Our version is essentially identical to Kwiatkowski's version that included an added picophytoplankton group, except that this latter group has been removed and replaced by a Trichodesmium compartment. Here we only highlight the main characteristics of the model and the specifics of our model version. Our version of PISCES-QUOTA has 39 prognostic compartments. As in the standard PISCES version, phytoplankton growth is limited by the availability of five nutrients: nitrate as well as ammonium, phosphate, silicate, and iron. Five living compartments are represented: three phytoplankton groups corresponding to nanophytoplankton, diatoms, and Trichodesmium and two zooplankton size classes that are microzooplankton and mesozooplankton. The elemental composition of phytoplankton and non-living organic matter is variable and is prognostically predicted by 
the model. On the other hand, zooplankton are assumed to be strictly homeostatic, i.e. their stoichiometry is kept constant (e.g. Meunier et al., 2014; Sterner and Elser, 2002). Nutrient uptake and assimilation as well as limitation of growth rate are modelled according to the chain model of Pahlow and Oschlies (2009). The P quota limits $\mathrm{N}$ assimilation which in turns limits phytoplankton growth. The phosphorus to nitrogen ratios of phytoplankton are described based on the potential allocation between P-rich biosynthesis machinery, N-rich light harvesting apparatus, a nutrient uptake component, the carbon stores, and the remainder (Daines et al., 2014; Klausmeier et al., 2004). This allocation depends on the cell size and on the environmental conditions.

Nutrients are delivered to the ocean through dust deposition, river runoff, and mobilization from the sediment. The atmospheric deposition of iron is derived from a climatological dust simulation (Tegen and Fung, 1995). The iron from sediment is recognized as a significant source (Johnson et al., 1999; Moore et al., 2004). This iron source is indeed parameterized in PISCES as, basically, a time-constant flux of dissolved iron $\left(2 \mu \mathrm{mol} \mathrm{m} \mathrm{m}^{-2} \mathrm{~d}^{-1}\right)$ applied over the whole sediment surface and modulated depending only on depth. A detailed description of this sedimentary source is presented in Aumont et al. (2015). The initial conditions and biogeochemical fluxes (iron, phosphorus, nitrate, etc.) at the boundaries of our domain are extracted from the World Ocean Atlas 2009 (https://www.nodc.noaa.gov/OC5/WOA09/woa09data. html, last access: 12 July 2018).

\subsubsection{Trichodesmium compartment}

For the purpose of this study, we implemented an explicit representation of Trichodesmium in our PISCESQUOTA version. Therefore, as already stated, five living compartments are modelled with three phytoplankton groups (nanophytoplankton, diatoms, and Trichodesmium) and two zooplankton groups (microzooplankton and mesozooplankton). Similarly to nanophytoplankton, the equation of Trichodesmium evolution is computed as follows:

$$
\begin{aligned}
\frac{\partial \mathrm{Tri}_{\mathrm{C}}}{\partial t} & =\left(1-\delta^{\mathrm{Tri}}\right) \mu^{\mathrm{Tri}} \text { Tri }-\zeta_{\mathrm{NO}_{3}}^{\mathrm{Tri}} V_{\mathrm{NO}_{3}}^{\mathrm{Tri}}-\zeta_{\mathrm{NH}_{4}}^{\mathrm{Tri}} V_{\mathrm{NH}_{4}}^{\mathrm{Tri}} \\
& -m^{\text {Tri }} \frac{\mathrm{Tri}_{\mathrm{C}}}{K_{m}+\mathrm{Tri}_{\mathrm{C}}} \operatorname{Tri}_{\mathrm{C}}-s h \times \omega^{\mathrm{Tri}} P^{2} \\
& -g^{Z} \text { (Tri) } Z-g^{M}(\text { Tri }) M .
\end{aligned}
$$

In this equation, Tri $_{\mathrm{C}}$ is the carbon Trichodesmium biomass, and the seven terms on the right-hand side represent, respectively, growth, biosynthesis costs based on nitrate and ammonium, mortality, aggregation, and grazing by micro- and mesozooplankton.

In our configuration, the photosynthesis growth rate of Trichodesmium is limited by light, temperature, phosphorus, and iron availability. Photosynthesis growth rate of Tri- chodesmium $\mu^{\mathrm{Tri}}$ is computed as follows:

$\mu^{\mathrm{Tri}}=\mu_{\mathrm{FixN}_{2}}+\mu_{\mathrm{NO}_{3}}^{\mathrm{Tri}}+\mu_{\mathrm{NH}_{4}}^{\mathrm{Tri}}$,

where $\mu_{\mathrm{FixN}_{2}}$ denotes growth due to dinitrogen fixation, $\mu_{\mathrm{NO}_{3}}^{\mathrm{Tri}}$ and $\mu_{\mathrm{NH}_{4}}^{\mathrm{Tri}}$ represent growth sustained by $\mathrm{NO}_{3}^{-}$and $\mathrm{NH}_{4}^{+}$uptake, respectively. Moreover, a fraction of fixed nitrogen is released back to seawater, mainly as ammonia and dissolved organic nitrogen, by the simulated Trichodesmium compartment. Berthelot et al. (2015a) estimated this fraction to be less than $10 \%$ when considering all diazotrophs. We set this fraction at $5 \%$ of the total amount of fixed nitrogen. For the other nutrients (i.e. iron and phosphorus), the same fraction is also released.

Dinitrogen fixation is limited by the availability of phosphate, iron, and light and is modulated by temperature. Loss processes are natural mortality and grazing by zooplankton. Natural mortality is considered to be similar to the other modelled phytoplankton species. Grazing on Trichodesmium is rarely described, but it is admitted that Trichodesmium represents a poor source of food for zooplankton (O'Neil and Romane, 1992) especially because they contain toxins (Hawser et al., 1992). On the other hand, many species of copepods have been shown to be able to graze on Trichodesmium despite the strong concentrations of toxins (O'Neil and Romane, 1992). For these reasons we applied two different coefficients for the grazing preference by mesozooplankton and microzooplankton (Table 1). For microzooplankton, grazing preference is halved to account for Trichodesmium toxicity, and for mesozooplankton the grazing preference is similar to that of the other phytoplankton species. The complete set of equations of Trichodesmium is detailed in Appendix A. Table 1 presents the parameters that differ between nanophytoplankton and Trichodesmium.

This set-up reproduces dinitrogen fixation through an explicit representation of the Trichodesmium biomass (to be compared with the often used implicit parameterizations (Assmann et al., 2010; Aumont et al., 2015; Dunne et al., 2013; Maier-Reimer et al., 2005; Zahariev et al., 2008) that directly link environmental parameters to nitrogen fixation without requiring the Trichodesmium biomass to be simulated).

\subsection{Experimental set-up}

Below the set of experiments that have been performed in this study is summarized (Table 2). All climatological simulations have been run for 20 years from the same restart and only the last 19 years are considered in our diagnostics. We chose the above-described simulation explicitly modelling the Trichodesmium to be our reference experiment (hereafter referred to as "TRI"). In a second experiment called "TRI_NoFeSed", the model set-up is identical to the reference experiment, except that iron input from the sediments is turned off between $156^{\circ} \mathrm{E}$ and $120^{\circ} \mathrm{W}$. In a third experiment "TRI_imp", the explicit dinitrogen fixation module is 
Table 1. Models parameters for Trichodesmium (Tricho.) and nanophytoplakton (Nano.).

\begin{tabular}{|c|c|c|c|c|}
\hline Parameters & Symbol & Units & Value & Reference \\
\hline Maximum growth rate for Tricho. & $\mu_{\max }^{\operatorname{Tri}}$ & $\mathrm{d}^{-1}$ & 0.25 & Breitbarth et al. (2007) \\
\hline Maximum growth rate for Nano. & $\mu_{\max }^{\mathrm{Nano}}$ & $\mathrm{d}^{-1}$ & 1.0 & \\
\hline Initial slope P-I Tricho. & $\alpha \mathrm{I}$ & $\left(\mathrm{W} \mathrm{m}{ }^{-2}\right)^{-1} \mathrm{~d}^{-1}$ & 0.072 & $\begin{array}{l}\text { Breitbarth et al. (2008) } \\
\text { and Hood et al. (2001) }\end{array}$ \\
\hline Initial slope P-I Nano. & $\alpha \mathrm{I}$ & $\left(\mathrm{W} \mathrm{m}^{-2}\right)^{-1} \mathrm{~d}^{-1}$ & 2.0 & \\
\hline Microzoo preference for Tricho. & $p_{\text {Tri }}^{\mathrm{I}}$ & - & 0.5 & \\
\hline Microzoo preference for Nano. & $p_{\text {Nano }}^{t}$ & - & 1.0 & \\
\hline Maximum $\mathrm{Fe} / \mathrm{C}$ in Tricho. & $\theta_{\max \mathrm{Tri}}^{\mathrm{Fe}}$ & $\operatorname{mol~Fe}(\mathrm{mol} \mathrm{C})^{-1}$ & $1 \times 10^{-4}$ & Kustka et al. (2003) \\
\hline Maximum $\mathrm{Fe} / \mathrm{C}$ in Tricho. & $\theta_{\max , \text { Nano }}^{\mathrm{Fe}}$ & $\mathrm{mol} \mathrm{Fe}(\mathrm{mol} \mathrm{C})^{-1}$ & $4 \times 10^{-5}$ & \\
\hline Maintenance iron & $m$ & $\operatorname{mol~Fe}(\mathrm{mol} \mathrm{C})^{-1}$ & $1.4 \times 10^{-5}$ & Kustka et al. (2003) \\
\hline Maintenance use efficiency & $\beta$ & $\operatorname{molC}(\mathrm{mol} \mathrm{Fe})^{-1} \mathrm{~d}^{-1}$ & $1.4 \times 10^{-4}$ & Kustka et al. (2003) \\
\hline
\end{tabular}

Table 2. List and description of the different experiments.

\begin{tabular}{lll}
\hline Name & $\mathrm{N}_{2}$ fixation & Iron from sediment \\
\hline TRI & explicit & yes \\
TRI_NoFeSed & explicit & no \\
TRI_imp & implicit & yes \\
Wo_N2 & no & yes \\
\hline
\end{tabular}

replaced by the implicit parameterization described in $\mathrm{Au}-$ mont et al. (2015), where fixation depends directly on water temperature, nitrogen, phosphorus, and iron concentrations and light (no nitrogen fixers are simulated). Finally, a fourth experiment "Wo_N2" corresponds to a model set-up in which no explicit nor implicit description of dinitrogen fixation is activated.

Comparison between TRI and TRI_NoFeSed experiments enables us to estimate the impact of iron input from island sediments on the dinitrogen fixation, while the impact of dinitrogen fixation on the biogeochemical conditions in the Pacific Ocean can be investigated by comparing TRI and Wo_N2. Finally, the TRI and TRI_imp experiments are used to evaluate the added value of an explicit description of dinitrogen fixation relative to an implicit inexpensive parameterization.

\subsection{Observational datasets}

Several different databases have been used to evaluate the model skills. For nitrate and phosphate, the $0.5^{\circ}$ global CSIRO Atlas of Regional Seas (CARS; http://www.marine.csiro.au/ dunn/cars2009/, last access: 12 July 2018) has been used. Iron has been evaluated with the global database from Tagliabue et al. (2012) complemented with the dissolved iron data from the OUTPACE cruise (Guieu et al., 2018). This database is a compilation of 13125 dissolved iron observations covering the global ocean and encompassing the period
1978-2008. The global MARine Ecosytem DATa (MAREDAT; https://doi.pangaea.de/10.1594/PANGAEA.793246) database of $\mathrm{N}_{2}$ fixation has been expanded with data from recent cruises performed in the WTSP: MOORSPICE (Berthelot et al., 2017), DIAPALIS (Garcia et al., 2007), NECTALIS (http://www.spc.int/oceanfish/en/ofpsection/ ema/biological-research/nectalis, last access: 12 July 2018), PANDORA (Bonnet et al., 2015), OUTPACE (Bonnet et al., 2018), and Mirai (Shiozaki et al., 2014). This database contains 3079 data points at the global ocean scale, of which $\sim 1300$ are located in our simulated region (Luo et al., 2012). Finally, we have used surface chlorophyll concentrations from the GLOBCOLOUR project (http://hermes.acri.fr, last access: 12 July 2018) which spans the 1998-2013 time period.

\section{Results}

\subsection{Model validation}

In this subsection, we aim at validating our reference simulation "TRI" with the data previously presented. In the Pacific, phosphate and nitrate concentrations show maxima in the upwelling regions, i.e. along the western American coast, and in the equatorial upwelling (Fig. 1a, c), and minima in the subtropical gyres. First, phosphate patterns show modelled values and structures in qualitatively good agreement with observations, despite an underestimation in the areas of high concentrations as within the Costa Rica dome and along the Equator. In contrast, the nitrate structure shows larger biases. We observe concentrations higher than $1 \mu \mathrm{mol} \mathrm{L} \mathrm{L}^{-1}$ all along the Equator in CARS, while the model nitrate concentrations are lower than this value west of $170^{\circ} \mathrm{W}$. More generally the model tends to underestimate nitrate concentrations.

The regions most favourable for Trichodesmium can be defined by temperatures within $25-29^{\circ} \mathrm{C}$ (Breitbarth et al., 2007). The model reproduces relatively well the spatial distribution of this temperature preferendum. This distribution 

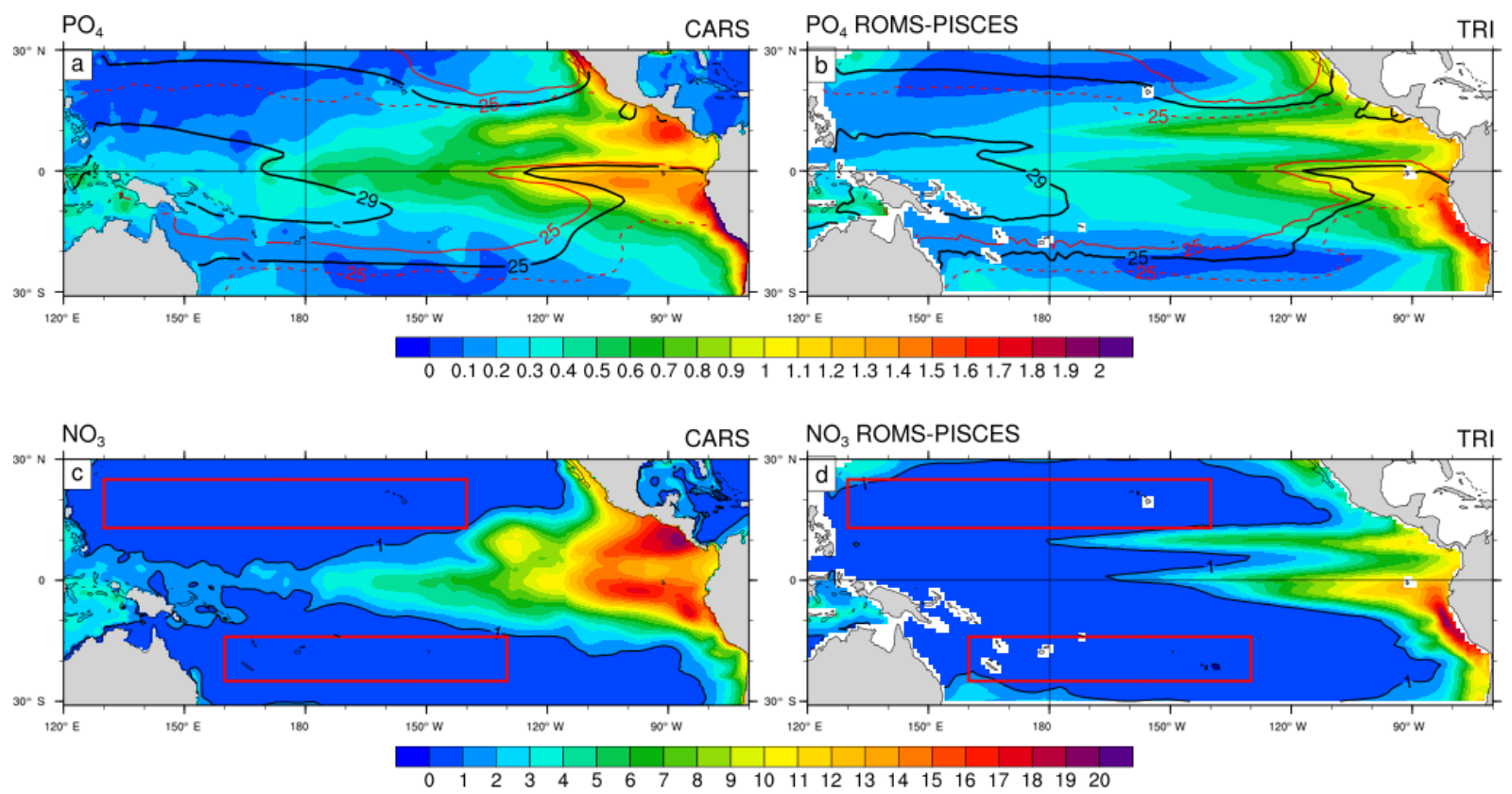

Figure 1. Annual mean concentrations in $\mu$ mol L-1 : (a) $\mathrm{PO}_{4}$ data from CARS (b) $\mathrm{PO}_{4}$ simulated by the ROMS-PISCES model (c) $\mathrm{NO}_{3}$ data from CARS (d) $\mathrm{NO}_{3}$ simulated by the ROMS-PISCES model. On panels (a) and (b), the black contours show the annual mean patterns of the temperature preferendum from observations (a) and the model (b). The red contours display the $25^{\circ} \mathrm{C}$ isoline in austral winter (plain) and in austral summer (dash). On panels (c) and (d) the red boxes represent the $\mathrm{LNLC}$ regions (defined as region where $\left[\mathrm{NO}_{3}^{-}\right]<1 \mu \mathrm{mol} \mathrm{L}^{-1}$ and $[\mathrm{Chl}]<0.1 \mathrm{mg} \mathrm{Chl} \mathrm{m}^{-3}$ ).
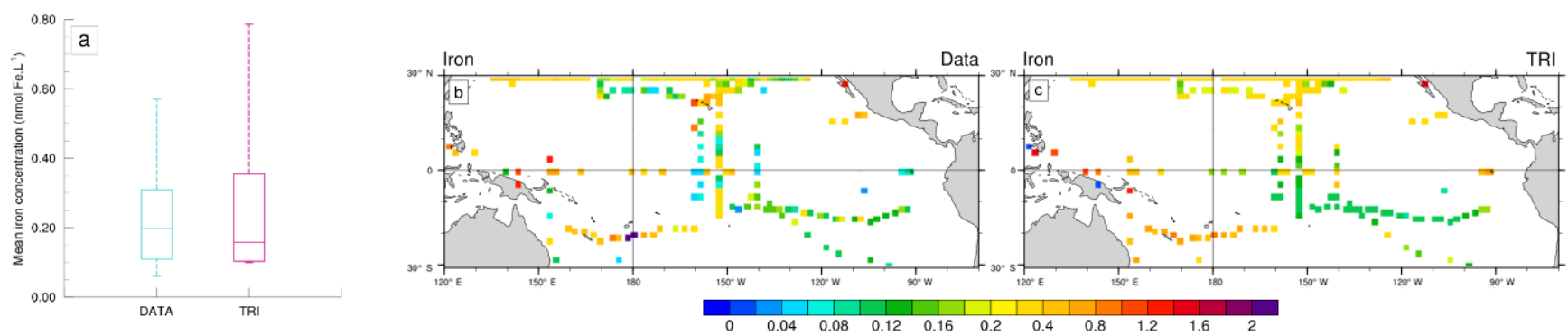

Figure 2. (a) Box plots of the $0-150 \mathrm{~m}$ averaged Iron $\left(\mathrm{nmol} \mathrm{Fe} \mathrm{L}^{-1}\right.$ ) data (blue) and the equivalent for the model (red) co-localized with the observations in space and time. The coloured box represents the $25-75 \%$ quartile of the distribution, the whiskers the $10-90 \%$ percentile distribution. The line inside the coloured box is the median. (b, c) Iron concentrations $\left(\mathrm{nmol} \mathrm{Fe} \mathrm{L}^{-1}\right)$ as observed (b) and as simulated by the model (c). Iron concentrations have been averaged over the top $150 \mathrm{~m}$ of the ocean. Model values have been sampled at the same location, the same month, and the same depth as the data.

exhibits a significant seasonal variability, mainly as a result of the variability of the $25^{\circ} \mathrm{C}$ isotherm. The latter moves by $\sim 7^{\circ}$ latitudinally between summer and winter in the WTSP, and by $\sim 15^{\circ}$ in the western tropical North Pacific (WTNP; Fig. 1a). This displacement is well reproduced in the TRI simulation (Fig. 1b). By contrast, along the Equator the mean position of the $25^{\circ} \mathrm{C}$ isotherm is shifted eastward in the TRI simulation $\left(120^{\circ} \mathrm{W}\right)$ compared to the observations $\left(125^{\circ} \mathrm{W}\right.$; Fig. 1a vs. b), but its seasonal displacements are well reproduced except in the southeastern Pacific. Overall, this temporal variability is well reproduced by the model (Fig. 1b), despite this bias. In contrast, nitrate and phosphate seasonal variability remains low (not shown).

Another important feature that needs to be properly reproduced by the model is the iron distribution in the upper ocean. We have sampled the modelled values at the same time and same location as the data. The median value, as well as the dispersion of the iron surface concentrations over the tropical Pacific, are displayed for both the data and the model in Fig. 2a. The Mann-Whitney test reveals that these two normalized distributions are not significantly different ( $p$ value $=0.26$ ). Figure $2 b, c$ display the observed iron field and the modelled values, respectively. The best sampled area 


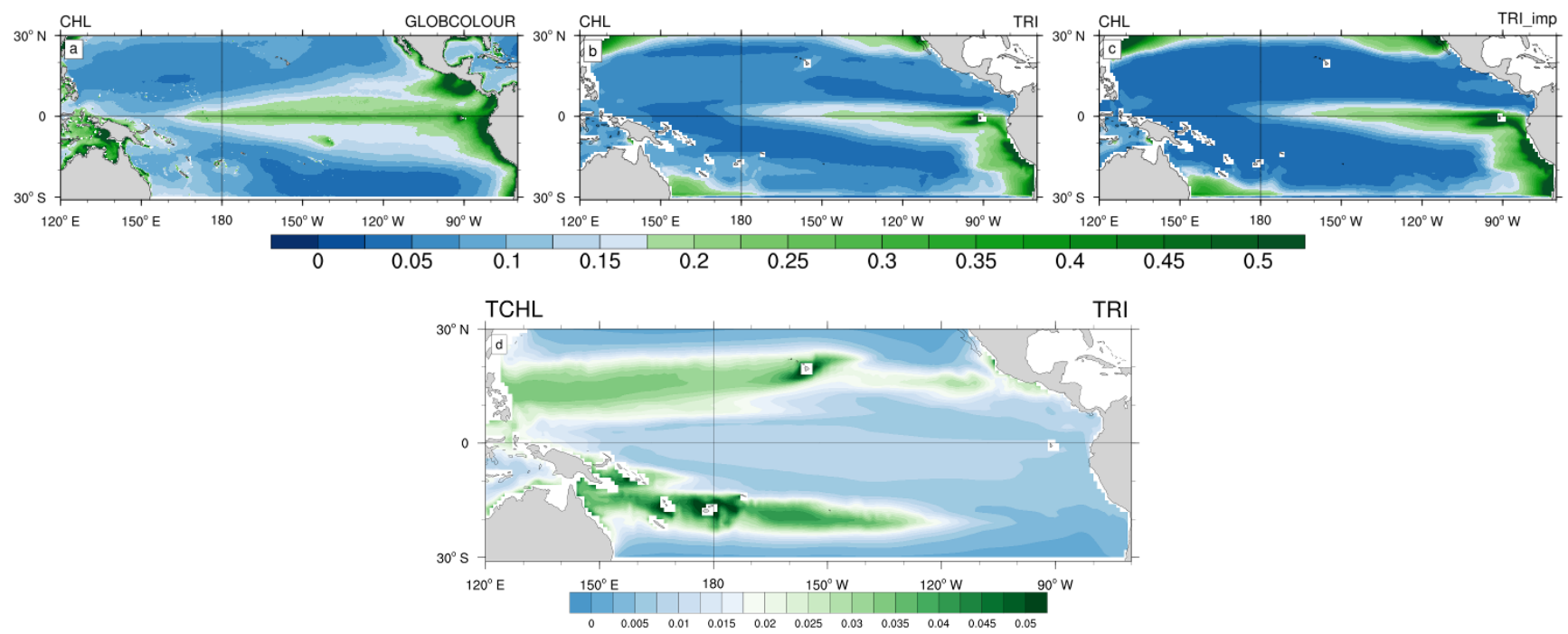

Figure 3. (a, b, c) Annual mean surface chlorophyll concentrations (in $\mathrm{mg} \mathrm{Chl} \mathrm{m}^{-3}$ ) from (a) GLOBCOLOUR data (b) TRI simulation and (c) TRI_imp simulation. Panel (d) shows the annual mean surface chlorophyll concentrations of Trichodesmium in the TRI simulation.

is the central Pacific Ocean where simulated iron concentrations are low $\left(0.1\right.$ to $0.3 \mathrm{nmol} \mathrm{Fe} \mathrm{L}^{-1}$, Fig. 2c), which is consistent with the observations (Fig. 2b). The southwest Pacific is characterized by relatively high surface iron concentrations, between 0.4 and $0.8 \mathrm{nmol} \mathrm{Fe} \mathrm{L}^{-1}$, both in the data and in the model. Large scale patterns are thus well represented by the model. Nevertheless, the model tends to overestimate iron levels in the South Pacific Gyre, between 180 and $140^{\circ} \mathrm{W}$ at about $20^{\circ} \mathrm{S}$.

Figure 3 displays a comparison between surface chlorophyll (Chl) concentrations from GLOBCOLOUR data (a), from TRI (b), and TRI_imp (c) simulations. High chlorophyll concentrations are found in the eastern equatorial Pacific upwelling and along Peru in both the observations and our two simulations, with mean values higher than $0.3 \mathrm{mg} \mathrm{Chl} \mathrm{m}^{-3}$. However, the equatorial chlorophyll maximum simulated by the model (Fig. 3b, c) is too narrow compared to the observations, especially in the Northern Hemisphere. Similarly, the model is unable to simulate the elevated chlorophyll levels around the Costa Rica dome and the localized enhanced chlorophyll off Papua New Guinea. In TRI (Fig. 3b), chlorophyll values in the southwest Pacific region vary between 0.1 and $0.2 \mathrm{mg} \mathrm{Chl} \mathrm{m}^{-3}$, with maxima located in the vicinity of the Fiji and Vanuatu islands. These values are within the range of the data, even if the data tend to be slightly higher (up to $0.3 \mathrm{mg} \mathrm{Chl} \mathrm{m}^{-3}$ near the coasts). The spatial structure is well represented, with maxima simulated around the islands. In the subtropical gyres, the simulation predicts chlorophyll concentrations of $\sim 0.05 \mathrm{mg} \mathrm{Chl} \mathrm{m}^{-3}$ which are higher than in the observations $\left(<0.025 \mathrm{mg} \mathrm{Chl} \mathrm{m}^{-3}\right)$. In contrast to TRI_imp (Fig. 3c), chlorophyll values in the southwest Pacific and in the Northern Hemisphere are too low in comparison with the ocean colour data (Fig. 3a).
Part of the surface chlorophyll in Fig. 3b is associated with Trichodesmium. Figure 3d shows the annual mean spatial distribution of surface Trichodesmium chlorophyll in the TRI simulation. This distribution displays two zonal tongues in the tropics, one in each hemisphere. Maximum values are located in the southwest Pacific (around Vanuatu archipelago, New Caledonia, Fiji, and Papua New Guinea) and around Hawaii, where they reach $0.06 \mathrm{mg} \mathrm{Chl} \mathrm{m}^{-3}$. In the South Pacific, high chlorophyll biomass extends eastward until $130^{\circ} \mathrm{W}$. Further east, concentrations drop to below $0.02 \mathrm{mg} \mathrm{Chl} \mathrm{m}^{-3}$. It is important to note that, in the observations, Trichodesmium have never been observed eastward of $170^{\circ} \mathrm{W}$. This bias in the model could be explained by the overestimated iron concentrations in the South Pacific Gyre. In the Northern Hemisphere, between the coasts of the Philippines $\left(120^{\circ} \mathrm{E}\right)$ and Hawaii $\left(140^{\circ} \mathrm{W}\right)$, Trichodesmium chlorophyll concentrations are greater than $0.03 \mathrm{mg} \mathrm{Chl} \mathrm{m}^{-3}$. In the northeast Pacific, Trichodesmium chlorophyll is lower, yet significant $\left(<0.03 \mathrm{mg} \mathrm{Chl} \mathrm{m}^{-3}\right)$. Otherwise the equatorial Pacific and southeast Pacific oceans are overall poor in Trichodesmium.

In Fig. 4, the dinitrogen fixation rates predicted by the model in TRI are compared to the observations from the MAREDAT expanded database. Evaluation of the model behaviour remains quite challenging because of the scarcity of the observations. Some large areas are not properly sampled such as the northwest tropical Pacific and the eastern $\mathrm{Pa}$ cific. In addition, some areas are sampled only in the surface layer $(0-30 \mathrm{~m})$, while others have been sampled deeper. This non-homogeneous sampling may alter the distribution of the $\mathrm{N}_{2}$ fixation rates and undermine the comparison with model outputs. To overcome this sampling bias we compared the observations with $\mathrm{N}_{2}$ fixation rates simulated and integrated 

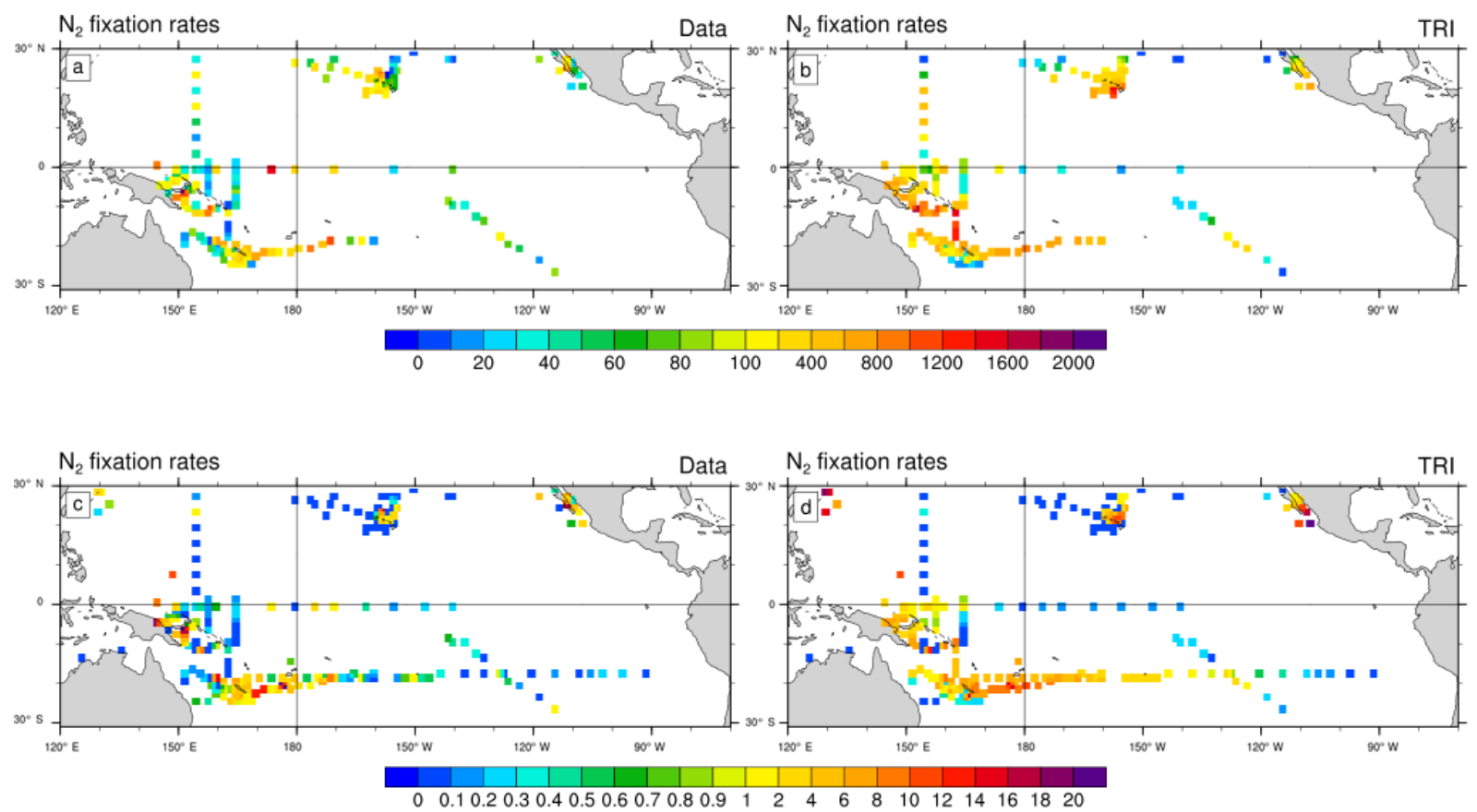

Figure 4. $\mathrm{N}_{2}$ fixation rates $\left(\mu \mathrm{mol} \mathrm{N} \mathrm{m} \mathrm{N}^{-2} \mathrm{~d}^{-1}\right)$ as observed $(\mathbf{a}, \mathbf{c})$ and as simulated by TRI simulation (b, d). In panels (a) and (b), $\mathrm{N}_{2}$ fixation rates have been integrated over the top $150 \mathrm{~m}$ of the ocean. In panels (c) and (d), the vertical integration has been restricted to the top $30 \mathrm{~m}$ of the ocean. Model values have been sampled at the same location, the same month (climatological month vs. real month), and the same depth as the data.

over two different layers (0-30 and 0-150 m). Despite their scarcity, some regional patterns emerge from the observations. Maximum fixation rates (600 to $1600 \mu \mathrm{mol} \mathrm{N} \mathrm{m}{ }^{-2} \mathrm{~d}^{-1}$; Fig. 4a) are observed around the southwest Pacific islands, in the Solomon Sea, around the Melanesian archipelagos, and around Hawaii, four well-known "hotspots" of $\mathrm{N}_{2}$ fixation (Berthelot et al., 2015b, 2017; Bonnet et al., 2009, 2017; Böttjer et al., 2017). The modelled regional patterns of strong fixation are coherent with the observations (Fig. 4b), showing values in the same range. In the South Pacific, the TRI simulation is able to reproduce the strong east-west increasing gradient of $\mathrm{N}_{2}$ fixation (Shiozaki et al., 2014; Bonnet et al., 2018; Fig. 4c, d). In the equatorial central Pacific, modelled values of mean fixation are negligible $(<$ $0.5 \mu \mathrm{mol} \mathrm{N} \mathrm{m}{ }^{-2} \mathrm{~d}^{-1}$ ) in contrast to the observations which suggest low but non-negligible fixation rates (between 1 and $2 \mu \mathrm{mol} \mathrm{N} \mathrm{m}{ }^{-2} \mathrm{~d}^{-1}$ ) (Bonnet et al., 2009; Halm et al., 2012). On the whole modelled domain, and for both integration layers, dinitrogen fixation rates are overestimated by $70 \%$ in TRI compared to the data. Some recent studies have shown that the ${ }^{15} \mathrm{~N}_{2}$ tracer addition method (Montoya et al., 2004) used in most studies reported in the MAREDAT database may underestimate $\mathrm{N}_{2}$ fixation rates due to an incomplete equilibration of the ${ }^{15} \mathrm{~N}_{2}$ tracer in the incubation bottles. Thus, this overestimation may be an artifact arising from methodological issues (Großkopf et al., 2012; Mohr et al., 2010). However, some other studies performed in the South
Pacific (Bonnet et al., 2016b; Shiozaki et al., 2015) compared the two methods, and did not find any significant differences.

\subsection{Trichodesmium primary production}

We evaluated the direct relative contribution of Trichodesmium to primary production (PP; Fig. 5). The spatial distribution of this contribution is very similar to the spatial distribution of Trichodesmium chlorophyll, with two distinct tongues located on each side of the Equator in the tropical domain. In the Northern Hemisphere, the tongue extends from the coast of the Philippines $\left(120^{\circ} \mathrm{E}\right)$ to Hawaii $\left(140^{\circ} \mathrm{W}\right)$ longitudinally and between 10 and $25^{\circ} \mathrm{N}$ latitudinally. The maximum contribution $(35 \%)$ is reached near Hawaii while in the rest of the tongue, values are close to $20 \%$. In the Southern Hemisphere, the region of elevated contribution extends from PNG $\left(140^{\circ} \mathrm{E}\right)$ to about the centre of the South Pacific subtropical gyre at $130^{\circ} \mathrm{W}$, and between 5 and $25^{\circ} \mathrm{S}$ latitudinally. Maximum values are predicted in the vicinity of Vanuatu and Fiji Islands, where they can reach $35 \%$. Part of this elevated contribution is explained by the very low PP rates simulated in this region for both nanophytoplankton and diatoms (less than $0.03 \mathrm{~mol} \mathrm{C} \mathrm{m}^{-3} \mathrm{yr}^{-1}$ ). Furthermore, the island effect seems to represent an important factor for explaining the spatial distribution of Trichodesmium growth rates. Indeed, maximum Trichodesmium chlorophyll concentrations and the largest contribution of Trichodesmium to PP are achieved near the islands. Finally, in LNLC regions (red 


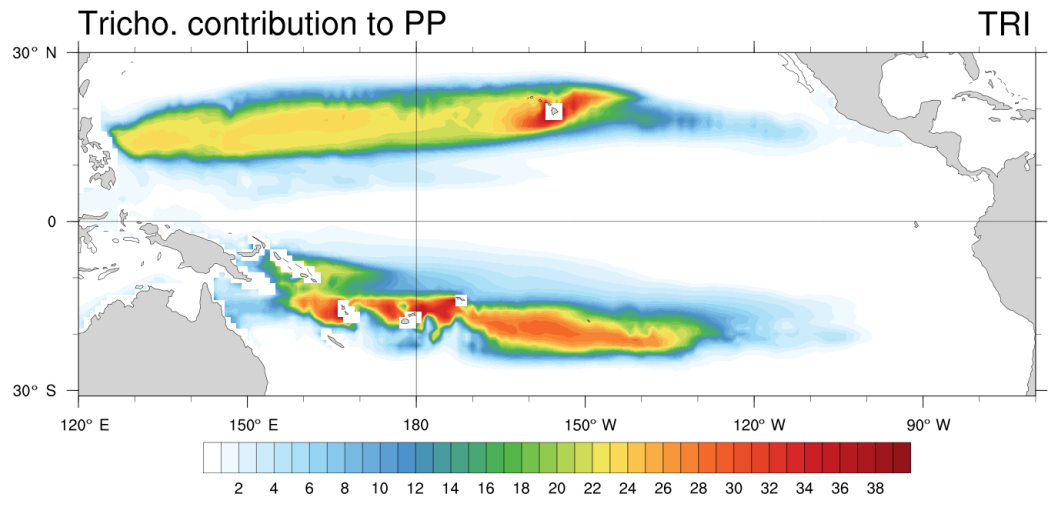

Figure 5. Relative contribution (in percentage) of Trichodesmium to total primary production.

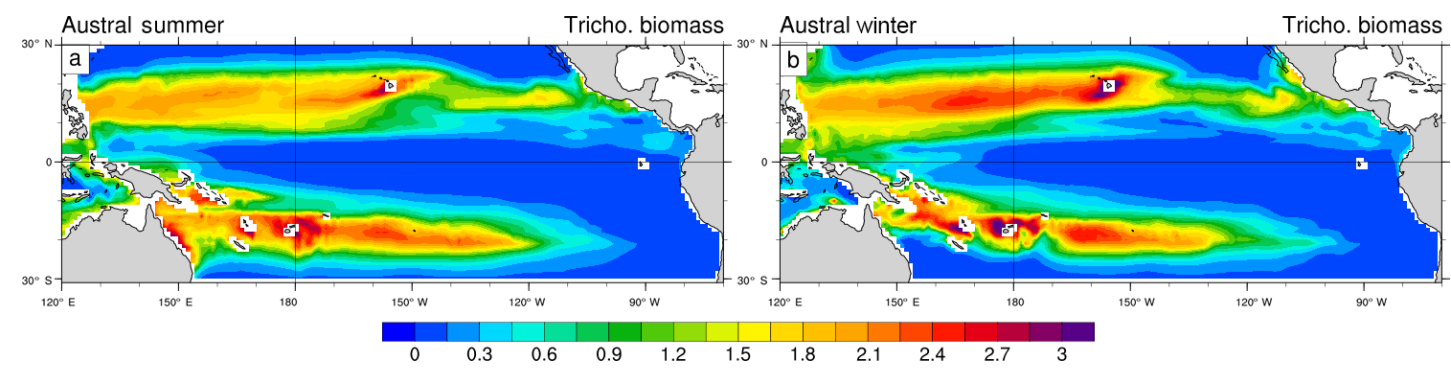

Figure 6. Trichodesmium biomass $\left(\mathrm{mmol} \mathrm{C} \mathrm{m}^{-2}\right)$ in (a) austral summer and (b) austral winter, integrated over the top $100 \mathrm{~m}$ of the ocean.

boxes; Fig. 1c, d), we assess that Trichodesmium contribute to $15 \%$ of total PP, which is in accordance with biogeochemical studies performed in these areas (Bonnet et al., 2015; Berthelot et al., 2017; Caffin et al., 2018).

\subsection{Seasonal variability in Trichodesmium biomass}

Trichodesmium biomass (Fig. 6) and simulated dinitrogen fixation rates (Fig. 7) display a seasonal variability that is driven by the seasonal variability of the environmental conditions (light, temperature, currents, nutrients). The regional maxima of Trichodesmium biomass (exceeding $3 \mathrm{mmol} \mathrm{C} \mathrm{m}{ }^{-2}$; integrated over the top $100 \mathrm{~m}$ of the ocean) are found in both hemispheres during the summer season (Fig. 6a, b) even if locally, maxima can be attained during other periods of the year than summer. In the South Pacific, the area of elevated Trichodesmium biomass moves by $3^{\circ}$ southward from austral winter to austral summer. Along Australia and in the Coral Sea, Trichodesmium biomass exhibits a large seasonal variability with a very low winter biomass that contrasts with elevated values in summer. A similar important variability, which is shifted by 6 months, is simulated in the Northern Hemisphere in the Micronesia region and in the Philippine Sea.

Unfortunately, due to the scarcity of $\mathrm{N}_{2}$ fixation data, this seasonal cycle cannot be properly assessed at the scale of the tropical Pacific Ocean. This is only feasible at the time series station ALOHA located in the North Pacific Gyre at $22^{\circ} 45^{\prime} \mathrm{N}$, $158^{\circ} \mathrm{W}$, where seasonal data of dinitrogen fixation are available from 2005 to 2012 (Böttjer et al., 2017). They proved that vertically integrated dinitrogen fixation rates are statistically significantly (one-way ANOVA, $p<0.01$ ) lower from November to March (less than $200 \mu \mathrm{mol} \mathrm{N} \mathrm{m} \mathrm{m}^{-2} \mathrm{~d}^{-1}$ ) than from April to October (about $263 \pm 147 \mu \mathrm{mol} \mathrm{N} \mathrm{m} \mathrm{m}^{-2} \mathrm{~d}^{-1}$ ) as highlighted in Fig. 7a (blue dots). In the model (red dots; Fig. 7a), the maximum amplitude of the seasonal cycle appears to be underestimated relative to the observations (i.e. respectively $\sim 170$ and $\sim 250 \mu \mathrm{mol} \mathrm{N} \mathrm{m}^{-2} \mathrm{~d}^{-1}$ ). Dinitrogen fixation peaks 1 month earlier in the model than in the data (August for the model and September for the data). Indeed, the simulated dinitrogen fixation rates are minimum between December and May (averaging $241 \pm 27 \mu \mathrm{mol} \mathrm{N} \mathrm{m} \mathrm{m}^{-2} \mathrm{~d}^{-1}$ ) and maximum the rest of the year (averaging $\sim 347 \pm 52 \mu \mathrm{mol} \mathrm{N} \mathrm{m}{ }^{-2} \mathrm{~d}^{-1}$ ). These values are comparable to the data even if they are slightly higher.

In order to assess the seasonal cycle of $\mathrm{N}_{2}$ fixation rates in the South Pacific (red box Fig. 1c; $160-230^{\circ}$ E, $25-14^{\circ} \mathrm{S}$ ), we have extracted the available data for each month from our database (blue dots; Fig. 7b), and the corresponding model values in TRI (red dots; Fig. 7b). In July no observations are available and in January, April, and August only one data point is available for the entire region. The predicted seasonal cycle is broadly consistent with the observations. Minimum dinitrogen fixation rates $\left(239 \pm 205 \mu \mathrm{mol} \mathrm{N} \mathrm{m}{ }^{-2} \mathrm{~d}^{-1}\right)$ occur during austral winter and autumn. Maximum rates are reached in February and March, where they exceed 

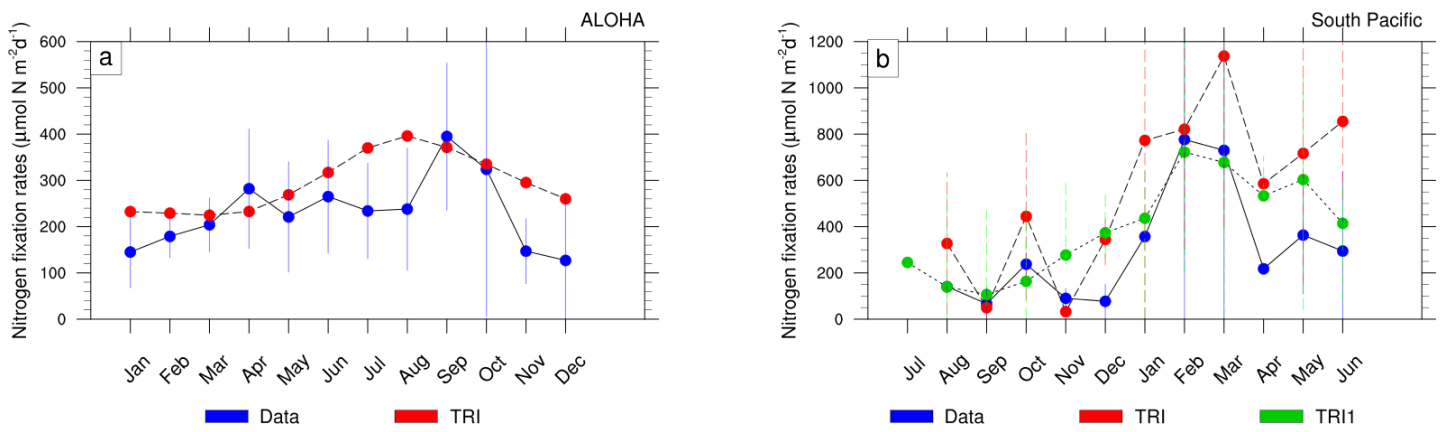

Figure 7. (a) Depth-integrated ( 0 to $125 \mathrm{~m}$ ) rates of $\mathrm{N}_{2}$ fixation $\left(\mu \mathrm{mol} \mathrm{N} \mathrm{m} \mathrm{m}^{-2} \mathrm{~d}^{-1}\right.$ ) at ALOHA for the data (blue) and TRI simulation (red). (b) Depth-integrated (from 0 to $150 \mathrm{~m}$ ) rates of $\mathrm{N}_{2}$ fixation $\left(\mu \mathrm{mol} \mathrm{N} \mathrm{m} \mathrm{m}^{-2} \mathrm{~d}^{-1}\right.$ ) in the South Pacific (red box, Fig. 1c) in the data (blue) and in the TRI simulation (red). The blue curve is the average of all the model points inside the South Pacific zone (red box, Fig. 1c), whereas the green curve corresponds to the average of the model points where data are available.

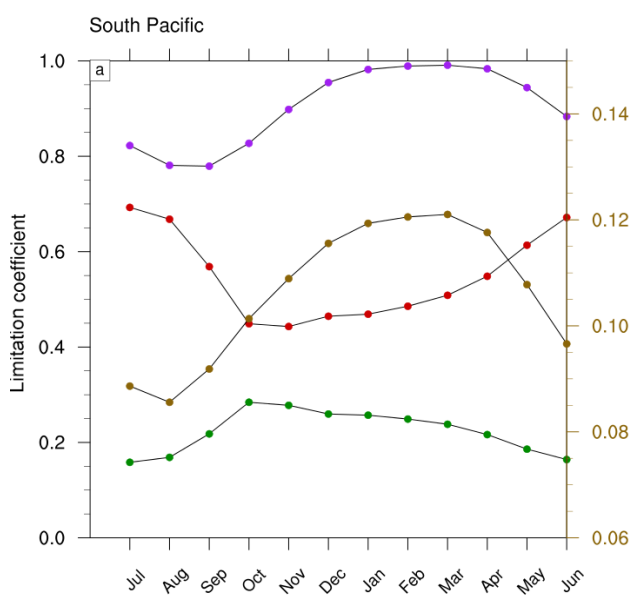

Iron

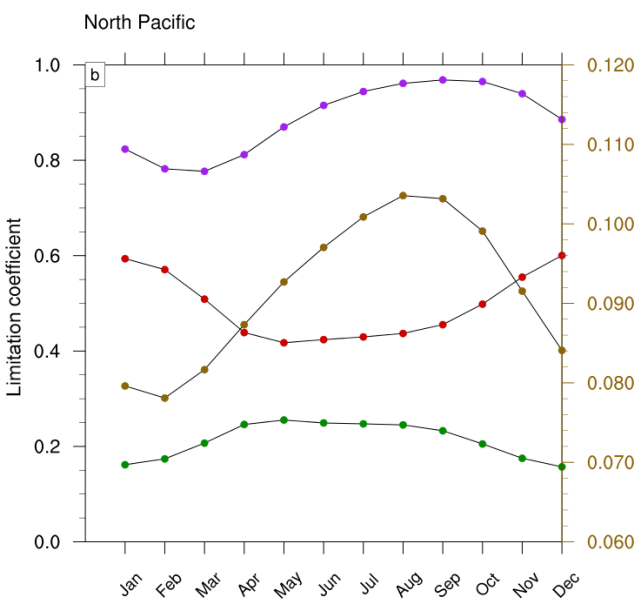

Light

All

Figure 8. Seasonal cycle of the limitation terms of Trichodesmium production in (a) the South Pacific and (b) the North Pacific. The right scale (in brown) represents the total limitation.

$600 \mu \mathrm{mol} \mathrm{N} \mathrm{m} \mathrm{m}^{-2} \mathrm{~d}^{-1}$ in the observations. The increase in dinitrogen fixation rates occurs 1 month earlier than in the observations, in December instead of January, and remains 2 to 3 fold higher from April to June. It is important to note here that the sampling spatial and temporal distribution may distort the seasonal cycle. Using the model, it is possible to evaluate how well the seasonal cycle is captured by the sampling (red dots compared to green dots; Fig. 7b). The general structure of the seasonal cycle remains relatively unaltered. However, the amplitude is significantly impacted since it reaches $1100 \mu \mathrm{mol} \mathrm{N} \mathrm{m} \mathrm{d}^{-1}$ if sampled at the observed stations, whereas it is about twice as low at $600 \mu \mathrm{mol} \mathrm{N} \mathrm{m}{ }^{-2} \mathrm{~d}^{-1}$ if all the model data points are considered. We can conclude that the TRI simulation reproduces well the seasonal cycle of $\mathrm{N}_{2}$ fixation rates at the Pacific scale, even though more data are needed to improve the evaluation of the model skills.
To further investigate the mechanisms that drive the seasonal variability in Trichodesmium in the Pacific, we examined the factors that control Trichodesmium abundance in the TRI simulation (not shown). This decomposition shows that the physical terms (advection and mixing) are negligible compared to biological terms. In addition, the seasonal cycles of grazing and mortality are in phase with the production terms but their sign is opposite. In conclusion, this analysis indicates that this seasonal variability is mainly controlled by the levels of PP, the other terms of tracer evolution dampen its amplitude but do not change its shape. Hence we further examine the limitation terms of PP (Fig. 8) in two representative regions characterized by elevated levels of $\mathrm{N}_{2}$ fixation rates (red boxes; Fig. 1c). A detailed description of these limitation terms is given in Appendix A. A limitation term reaching 1 means that growth is not limited, whereas a limitation term equal to 0 means that growth ceases. 
Trichodesmium growth sustained by nitrate and ammonia is very slow in LNLC regions due to their very low availability and is therefore not considered further. Thus, our analysis is restricted to dinitrogen fixation. Trichodesmium growth can be limited by iron and phosphate and is inhibited when reactive nitrogen (nitrate and ammonia) is available. In the WTSP, the model suggests that iron is the sole nutrient that modulates Trichodesmium growth (red curve; Fig. 8a, b). The other limiting factors of Trichodesmium growth are light (green curve; Fig. 8a, b) and temperature (purple curve; Fig. 8a, b). The product of these three limiting factors gives the limiting coefficient of dinitrogen fixation (brown curve; Fig. 8a, b). The limiting factors vary according to the season and the hemisphere. In the South (North) Pacific, temperature and light are less limiting during the austral summer (winter) than during the austral winter (summer). The limiting factor associated with temperature varies from 0.8 to 1 , and the light limiting factor varies from 0.15 to 0.3 . Unlike light and temperature, iron is less (more) limiting in the South (North) Pacific during winter (summer) than during the austral summer (winter) with values varying between 0.4 and 0.7 . Finally, Trichodesmium growth is more limited during austral winter (summer) in the South (North) Pacific. The seasonal variability is forced by light and temperature, and iron mitigates its amplitude. Indeed, nutrients and iron inputs brought to the euphotic zone by the seasonally enhanced vertical mixing are counterbalanced by the related inputs (e.g. temperature) of these water masses.

\section{Discussion}

\subsection{Impact of iron from island sediments}

Monteiro et al. (2011) performed a sensitivity study and found that a 5-fold increase in the solubility of aeolian iron improves the biogeographical distribution of $\mathrm{N}_{2}$ fixation in the southwest Pacific. In the meantime, a recent study has challenged this view by showing no increase in $\mathrm{N}_{2}$ fixation in response to increased dust deposition (Luo et al., 2014). In any cases, the sedimentary and hydrothermal sources were not taken into account in those studies, although they are likely significant sources (Bennett et al., 2008; Johnson et al., 1999; Moore et al., 2004; Tagliabue et al., 2010; Toner et al., 2009). In parallel, Dutkiewicz et al. (2012) evaluated the sensitivity of the biogeographical distribution of $\mathrm{N}_{2}$ fixation to the aeolian source of iron in a model which takes into account the iron sediment supplies, and conclude for minor changes in the southwest Pacific, while in the North Pacific the change was larger. Indeed, there are many islands with a marked orography that could deliver significant amounts of iron to the ocean (Radic et al., 2011) in the southwest Pacific.

To assess the impact of the sediment source of iron on the Trichodesmium production, we used the "TRI_NoFeSed" experiment in which this specific source of iron has been turned off for the islands between $156^{\circ} \mathrm{E}$ and $120^{\circ} \mathrm{W}(\mathrm{Ta}-$ ble 2). In this simulation, iron and Trichodesmium chlorophyll decrease by 58 and $51 \%$, respectively (Fig. 9a, b), in the WTSP (red box Fig. 1c). Figure 9c displays the iron distribution simulated in TRI_NoFeSed, and shows that the maxima around the islands disappear. Furthermore, in the South Pacific, iron decreases due to the reduction of the zonal advection of iron downstream of the islands. The iron flux from the sediments around the islands also affects the spatial structure of Trichodesmium chlorophyll (Fig. 9e, f), most noticeably in the South Pacific, with maxima shifted from the South Pacific islands region (e.g. Fiji, New Caledonia, Vanuatu) in the TRI simulation to the coastal regions near Australia and Papua New Guinea in the TRI_NoFeSed simulation. In the Northern Hemisphere, the effects of the sediment flux of iron are less important with a shift of the Trichodesmium chlorophyll maxima towards the Philippine Sea and a localized effect near Hawaii. This sensitivity test demonstrates that Trichodesmium are highly sensitive to the iron distribution in our model and hence that the spatial patterns of Trichodesmium chlorophyll in the southwest Pacific are tightly controlled by the release of iron from the coastal sediments of the Pacific islands.

\subsection{Trichodesmium impacts on biogeochemistry}

One of the questions we want to address is the quantification of the Trichodesmium impact on PP, at the Pacific scale with a focus on the WTSP region. In the oligotrophic waters of the South Pacific, dinitrogen fixation can be an important source of bio-available nitrogen in the water column through Trichodesmium recycling which can feed other phytoplankton. To evaluate that impact, we calculated the relative increase in PP between the TRI simulation and the Wo_N2 simulation in which no $\mathrm{N}_{2}$ fixation is considered (Fig. 10a). As expected, the spatial structure of the PP differences between both simulations matches the $\mathrm{N}_{2}$ fixation spatial distribution in the TRI simulation (two tongues, one in each hemisphere). In the North Pacific the maximum increase in the PP due to the $\mathrm{N}_{2}$ fixation is located around Hawaii, where it exceeds $120 \%$. In the remaining part of the Northern Hemisphere tongue, PP increases by 50 to $100 \%$. In the Southern Hemisphere, values are more homogeneous in the tongue (from 80 to $100 \%$ ), even though there is a local maximum around Fiji and Vanuatu (up to $120 \%$ ). Out of these northern and southern tongues, the increase in PP is less than $20 \%$. In average on our domain, the increase in PP is $19 \%$, and in LNLC regions it reaches approximately $50 \%$.

From total PP only, it is not possible to disentangle the increase in PP directly due to Trichodesmium themselves and the indirect increase due to the impact of $\mathrm{N}_{2}$ fixation on the other phytoplankton groups (nanophytoplankton and diatoms). Indeed, as mentioned in the Methods section, Trichodesmium also releases a fraction of the recently fixed $\mathrm{N}_{2}$ as bio-available nitrogen (in our model Trichodesmium re- 

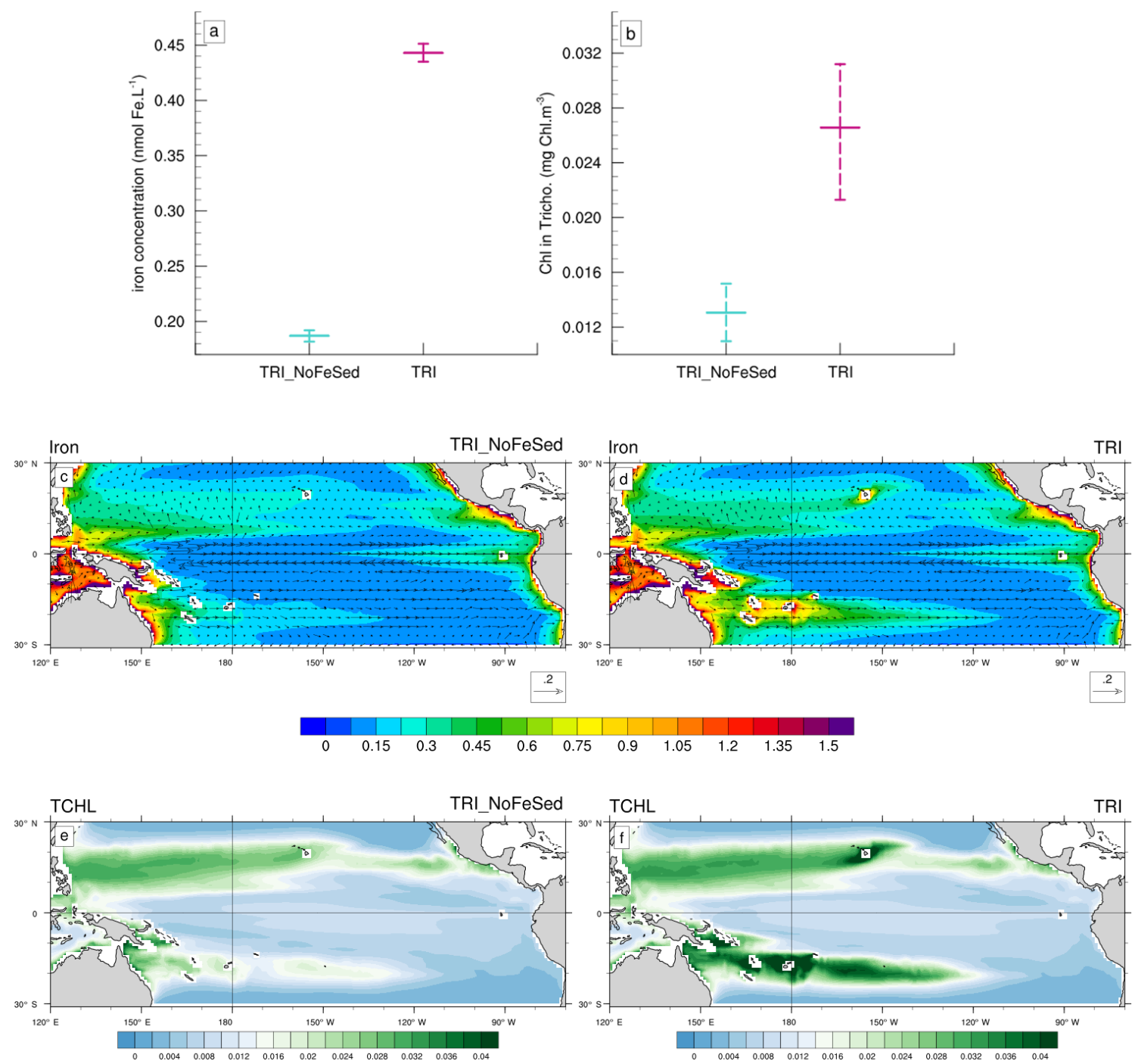

Figure 9. (a, b) Minimum, mean and maximum in the South box (Fig. 1c) of (a) the iron concentrations (in $\mathrm{nmol} \mathrm{Fe} \mathrm{L}^{-1}$ ), and (b) of the chlorophyll concentrations of Trichodesmium (in $\mathrm{mg} \mathrm{Chl} \mathrm{m}^{-3}$ ). (c, $\mathbf{d}, \mathbf{e}, \mathbf{f}$ ) Annual mean iron concentrations (shading; in $\mathrm{nmol} \mathrm{Fe} \mathrm{L}^{-1}$ ) and current velocities (vectors; in $\mathrm{m} \mathrm{s}^{-1}$ ) for (c) the TRI_NoFeSed simulation and (d) the TRI simulation. Annual mean chlorophyll concentrations of Trichodesmium $\left(\mathrm{mg} \mathrm{Chl} \mathrm{m}^{-3}\right)$ for (e) the TRI_NoFeSed simulation and (f) the TRI simulation. The concentrations have been averaged over the top $100 \mathrm{~m}$ of the ocean. The current velocities are identical on the panels (a) and (b).

leases ammonia and dissolved organic nitrogen, but only ammonia is directly bio-available). Figure $10 \mathrm{~b}$ displays the difference in PP due to diatoms and nanophytoplankton only. The main large-scale patterns constituted of the northern and southern tongues persist, but the intensity of the differences contrasts with those found when considering total PP (Fig. 10a). Indeed, the increase in total PP (Fig. 10a) in those two tongues is twice as high as when the direct effect of Trichodesmium is excluded. This analysis stresses the importance of the bio-available nitrogen released by diazotrophs as we attribute about half of the total production increase to this release. Indeed, recent isotopic studies tracing the passage of diazotroph-derived nitrogen into the planktonic food web reveal that part of the recently fixed nitrogen is released to the dissolved pool and quickly taken up (24-48\%) by surrounding planktonic communities (Berthelot et al., 2016; Bonnet et al., 2016b, a).

With the simulation TRI_imp, we aim at comparing an implicit $\mathrm{N}_{2}$ fixation formulation to the explicit formulation used in TRI. Figure 10c displays the relative change of total PP between the TRI and the TRI_imp simulations (see Table 2). The implicit formulation displays a similar spatial distribution to that of the explicit distribution but it is predicting a lower total PP, especially in the southern Pacific where explicit formulation leads to an increase of about $45 \%$ in total PP compared to the one related to the implicit formulation. On average across our domain, total PP is about $9 \%$ higher 

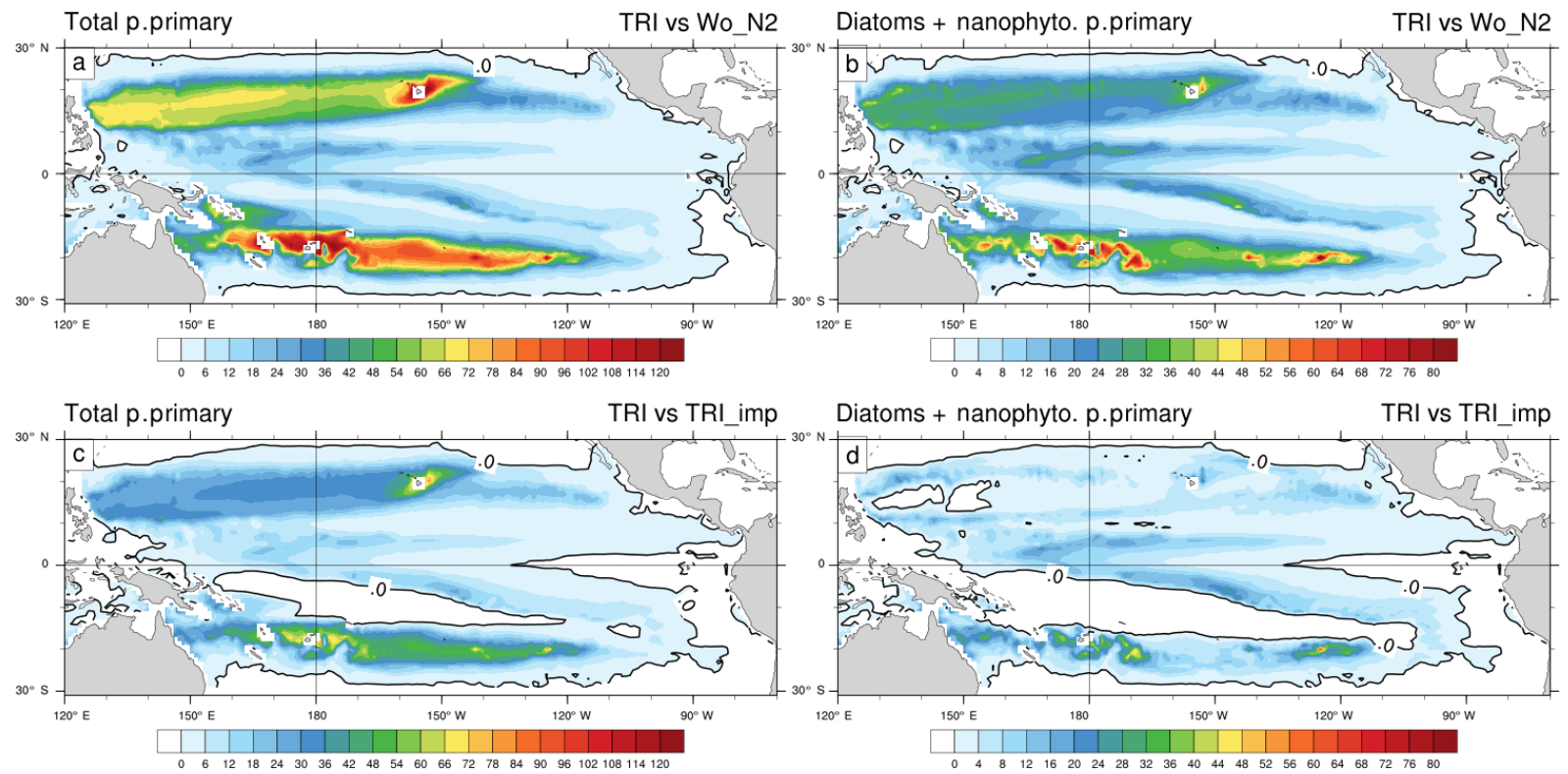

Figure 10. Percentage increase in primary production between the TRI simulation and the Wo_N2 simulation (a, b) and the TRI_imp simulation (c, d); panels (a) and (c) show total primary production including the contribution of Trichodesmium whereas in panels (b) and (d), primary production only includes the contribution of diatoms and nanophytoplankton.

when nitrogen fixation is explicitly modelled relative to an implicit formulation.

This difference becomes even weaker $(2 \%)$ if only PP by nanophytoplankton and diatoms is considered, with noticeable differences restricted to the areas of maximum $\mathrm{N}_{2}$ fixation in the Southern Hemisphere (around the islands). PP sustained by the release of bio-available nitrogen is thus similar in the TRI and TRI_imp simulations, but an explicit representation of $\mathrm{N}_{2}$ fixation allows for a better description of $\mathrm{N}_{2}$ fixation patterns. Indeed, the areas of intense $\mathrm{N}_{2}$ fixation rates cannot be properly simulated in the vicinity of the islands, especially in the Southern Hemisphere, by the tested implicit parameterization. We also assessed the carbon export (under the euphotic layer, mmol C s $\mathrm{d}^{-1}$; Fig. $\mathrm{S} 1$ in the Supplement) and the $\mathrm{N}_{2}$ fixation rate (integrated over the top to $150 \mathrm{~m}$; Fig. S2: panel (a) in $\mu \mathrm{mol} \mathrm{N} \mathrm{m}^{-2} \mathrm{~d}^{-1}$ and panel (b) in percentage) difference between TRI and TRI_imp simulations. We observe a carbon export greater in the TRI simulation, the average across the Pacific of this difference is $0.1 \mathrm{mmol} \mathrm{C} \mathrm{m}^{-2} \mathrm{~d}^{-1}$ or $4 \%$, and in LNLC regions the increase varies between 6 and $10 \%$. The $\mathrm{N}_{2}$ fixation rates are greater in TRI simulation except in the warm pool, in the equatorial upwelling, and in the Peruvian upwelling.

\subsection{Limitations of the present study}

In this study, we simulate $\mathrm{N}_{2}$ fixation through the explicit representation of only one type of diazotrophs, the Trichodesmium sp. This choice has been motivated by evidences that it represents one of the main nitrogen fixers in the western tropical Pacific (Bonnet et al., 2015; Dupouy et al., 2011;
Shiozaki et al., 2014) and by the relatively good knowledge (compared to other dinitrogen fixers) we have about its physiology (Ramamurthy and Krishnamurthy, 1967; Ohki et al., 1992; Mulholland and Capone, 2000; Mulholland et al., 2001; Küpper et al., 2008; Rubin et al., 2011; Bergman et al., 2013). However, our model remains simple and some of the mechanisms that drive the behaviour of Trichodesmium have not been implemented in our model. As an example, the ability of Trichodesmium to group in colonies and to vertically migrate (Kromkamp and Walsby, 1992; Villareal and Carpenter, 2003; Bergman et al., 2013) is well documented. The reason for these mechanisms remains unclear, but several hypotheses have been put forward such as avoiding nitrogenase exposition to di-oxygen (Carpenter, 1972; Gallon, 1992; Paerl et al., 1989), or maximizing light (on the surface) and nutrient (at depth) acquisition (Letelier and Karl, 1998; Villareal and Carpenter, 1990; White et al., 2006), or even increasing the efficiency of the uptake of atmospheric iron (Rubin et al., 2011). Our model does not represent those processes nor does it model the resulting vertical migration of Trichodesmium. Moreover, the release of fixed dinitrogen as reactive nitrogen bioavailable to other phytoplanktonic organisms has been set to a constant value of $5 \%$. This percentage is known to be highly variable and therefore this value is in the lowest range of the observations. An increase in this value would increase the PP due to nanophytoplankton and diatoms in the TRI simulation, and thus decrease the relative contribution of Trichodesmium to total PP, which would be closer to the last observations (Berthelot et al., 2017; Bonnet et al., 2017). 
Some studies, mostly based on extrapolated in situ data, aimed at assessing the potential of $\mathrm{N}_{2}$ fixation at global or regional scale (Codispoti et al., 2001; Deutsch et al., 2001; Galloway et al., 2004). In the south western tropical Pacific, Bonnet et al. (2017) have estimated total $\mathrm{N}_{2}$ fixation at 15 to $19 \mathrm{Tg} \mathrm{N} \mathrm{yr}^{-1}$. For the same region, $\mathrm{N}_{2}$ fixation is predicted to amount to $\sim 7 \mathrm{Tg} \mathrm{Nyr}^{-1}$ in the TRI simulation. As already mentioned, this rather low predicted estimate might be explained by the sole representation of Trichodesmium as nitrogen fixing organisms, which dominate in the western tropical South Pacific (Dupouy et al., 2011; Stenegren et al., 2018). It has to be noted that other diazotroph groups such UCYN-B and DDAs are abundant in the WTSP, representing 10-20\% of the overall diazotroph community (Stenegren et al., 2018). Moreover, the contribution of heterotrophic diazotrophic organisms is poorly studied and may account for a significant fraction of $\mathrm{N}_{2}$ fixation (Moisander et al., 2017). Our model estimation has also been computed from monthly averages and is thus not taking into account the high-frequency variability that may explain at least some of the very high rates of $\mathrm{N}_{2}$ fixation found in the study by Bonnet et al. (2017). Our assessment based on a model could thus be seen as a lower limit for $\mathrm{N}_{2}$ fixation in the western tropical Pacific. Moreover, our model also shows a good qualitative agreement with the studies based on observations that focus on the impact of $\mathrm{N}_{2}$ fixation in tropical oligotrophic waters (Raimbault and Garcia, 2008; Shiozaki et al., 2013). Indeed, in agreement with those studies, our reference simulation predicts that diazotrophs support a significant part of total PP $(15 \%)$ in LNLC regions.

\section{Conclusion}

This study describes the spatial and temporal distribution of Trichodesmium at the scale of the tropical Pacific Ocean, and investigates the impact of a major diazotroph species (e.g. Trichodesmium sp.) on the biogeochemistry of this region. Towards this end, we performed a first 20-year simulation with the coupled 3-D dynamical-biogeochemical model ROMS-PISCES in which we embedded an explicit representation of $\mathrm{N}_{2}$ fixation based on Trichodesmium physiology. This simulation was shown to be able to reproduce the main physical (SST) and biogeochemical (nutrient) conditions of the tropical Pacific Ocean. This includes the spatial distribution of surface chlorophyll and $\mathrm{N}_{2}$ fixation.
The validation of this simulation allows us to confidently assess the Trichodesmium distribution. The model predicts that areas favourable to Trichodesmium growth extend from $150^{\circ} \mathrm{E}$ to $120^{\circ} \mathrm{W}$ in the South Pacific, and from $120^{\circ} \mathrm{E}$ to $140^{\circ} \mathrm{W}$ in the North Pacific, with local optimal conditions around the islands (i.e. Hawaii, Fiji, Samoa, New Caledonia, Vanuatu). This broadly corresponds to the LNLC regions where Trichodesmium are predicted to be responsible for $15 \%$ of total primary production (PP). The seasonal variability of the Trichodesmium habitat is dominantly controlled by SST and light, while iron availability modulates the amplitude of the seasonal cycle.

In our study we also assess the role played by iron released from the island sediments, and show that this iron source partly controls the spatial structure and the abundance of Trichodesmium in the western tropical South Pacific. However, this region is in the centre of the South Pacific Convergence Zone, which is the largest convective area of the Southern Hemisphere, with rainfall exceeding $6 \mathrm{~mm} \mathrm{~d}^{-1}$, hence it would be interesting to assess the impact of river iron supply on the diazotroph activity. In addition, the Vanuatu archipelago and Tonga are located on the ring of fire, hence hydrothermal sources could have a strong impact on $\mathrm{N}_{2}$ fixation. These two iron sources are not yet implemented in our configuration but may improve simulations of $\mathrm{N}_{2}$ fixation in the southwestern tropical Pacific region. Finally, our explicit simulation of $\mathrm{N}_{2}$ fixation has proven to be higher by $25 \%$ (while still in the lower end of estimations from observations) than the more commonly used implicit parameterization.

Data availability. Data are available upon request. 


\section{Appendix A}

Trichodesmium preferentially fixes $\mathrm{N}_{2}$ at temperatures between $20-34{ }^{\circ} \mathrm{C}$ (Breitbarth et al., 2007). The temperature effect on the growth rate is modelled using a 4 th order polynomial function (Ye et al., 2012):

$$
\begin{aligned}
L_{T}^{\mathrm{Tri}} & =\left(2.32 \times 10^{-5} \times T^{4}-2.52 \times 10^{-3} \times T^{3}\right. \\
& \left.+9.75 \times 10^{-2} \times T^{2}-1.58 \times T+9.12\right) / 0.25,
\end{aligned}
$$

where $0.25 \mathrm{~d}^{-1}$ is the maximum observed growth rate (Breitbarth et al., 2007). Hence, at $17^{\circ} \mathrm{C}$ the growth rate is zero and maximum growth rate is reached at $27^{\circ} \mathrm{C}$. The Trichodesmium light limitation is similar to nanophytoplankton (Aumont et al., 2015).

From Eq. (2), we distinguish two cases for the growth rate due to $\mathrm{N}_{2}$ fixation.

If phosphorus is limiting, Eq. (2) becomes

$$
\begin{aligned}
& \mu_{\mathrm{FixN}}=\mu_{\max }^{\mathrm{Tri}} \cdot L_{\mathrm{I}}^{\mathrm{Tri}} \cdot L_{\mathrm{P}}^{\mathrm{Tri}}-\left(\mu_{\mathrm{NO}_{3}}^{\mathrm{Tri}}+\mu_{\mathrm{NH}_{4}}^{\mathrm{Tri}}\right) \text { with } \\
& L_{\mathrm{P}}^{\mathrm{Tri}}=\min \left(1, \max \left(0, \frac{\left(\theta^{\mathrm{P}}-\theta_{\min }^{\mathrm{P}}\right) \times \theta_{\max }^{\mathrm{P}}}{\left(\theta_{\max }^{\mathrm{P}}-\theta_{\min }^{\mathrm{P}}\right) \times \theta^{\mathrm{P}}}\right)\right) .
\end{aligned}
$$

If iron is limiting,

$$
\begin{aligned}
& \mu_{\mathrm{FixN}}=\mu_{\max }^{\mathrm{Tri}} \cdot L_{\mathrm{I}}^{\mathrm{Tri}} \cdot L_{\mathrm{Fe}}^{\mathrm{Tri}}-\left(\mu_{\mathrm{NO}_{3}}^{\mathrm{Tri}}+\mu_{\mathrm{NH}_{4}}^{\mathrm{Tri}}\right) \text { with } \\
& L_{\mathrm{Fe}}^{\mathrm{Tri}}=\min \left(1, \max \left(0, \frac{\left(\theta^{\mathrm{Fe}}-\theta_{1}^{\mathrm{Fe}}\right) \times \theta_{\mathrm{opt}}^{\mathrm{Fe}}}{\left(\theta_{\mathrm{opt}}^{\mathrm{Fe}}-\theta_{0}^{\mathrm{Fe}}\right) \times \theta^{\mathrm{Fe}}}\right)\right) .
\end{aligned}
$$

In Eq. (A3b), $\theta_{1}^{\mathrm{Fe}}$ and $\theta_{0}^{\mathrm{Fe}}$ are computed as follows :

$\theta_{1}^{\mathrm{Fe}}=\theta_{0}^{\mathrm{Fe}}+\alpha \cdot \mu_{\mathrm{FixN}_{2}}$,

$\theta_{0}^{\mathrm{Fe}}=\theta_{\min }^{\mathrm{Fe}}+m$,

$\alpha=\frac{1}{\beta}$, where $\theta^{\text {Nutrients }}$ represents the nutrient quota for iron and phosphorus (i.e. the ratio between iron and carbon concentrations in Trichodesmium, for instance). $\theta_{\min }^{\mathrm{P}}$ and $\theta_{\mathrm{opt}}^{\mathrm{Fe}}$ are constants, whereas $\theta^{\text {Nutrients }}$ varies with time. The minimum between $L_{\mathrm{Fe}}^{\mathrm{Tri}}$ and $L_{\mathrm{P}}^{\mathrm{Tri}}$ defines the limiting nutrient. $L_{\mathrm{I}}^{\mathrm{Tri}}$ is the limiting function by temperature and light. $m$ is the difference between the maintenance iron (i.e. the intracellular $\mathrm{Fe}: \mathrm{C}$ present in the cell at zero growth rate) for a diazotrophic growth and a growth on ammonium (Kustka et al., 2003). $\beta$ is the marginal use efficiency and equals the moles of additional carbon fixed per additional mole of intracellular iron per day (Raven, 1988; Sunda and Huntsman, 1997). The demands for iron in phytoplankton are for photosynthesis, respiration, and nitrate/nitrite reduction. Following Flynn et al. (1997), we assume that the rate of synthesis of new components requiring iron by the cell is given by the difference between the iron quota and the sum of the iron required by these three sources of demand, which we defined as the actual minimum iron quota:

$$
\begin{aligned}
\theta_{\min }^{\mathrm{Fe}} & =\frac{0.0016}{55.85} \theta_{\mathrm{Tri}}^{\mathrm{Chl}}+\frac{1,21.10^{-5} \times 14}{55.85 \times 7.625} L_{\mathrm{N}}^{\mathrm{Tri}} \times 1.5 \\
& +\frac{1.15 \times 10^{-4} \times 14}{55.85 \times 7.625} L_{\mathrm{NO}_{3}}^{\mathrm{Tri}} .
\end{aligned}
$$

In this equation, the first right-hand side term corresponds to photosynthesis, the second term corresponds to respiration, and the third term estimates nitrate and nitrite reduction. The parameters used in this equation are directly taken from Flynn and Hipkin (1999). 
Supplement. The supplement related to this article is available online at: https://doi.org/10.5194/bg-15-4333-2018-supplement.

Competing interests. The authors declare that they have no conflict of interest.

Special issue statement. This article is part of the special issue "Interactions between planktonic organisms and biogeochemical cycles across trophic and $\mathrm{N}_{2}$ fixation gradients in the western tropical South Pacific Ocean: a multidisciplinary approach (OUTPACE experiment)". It is not associated with a conference.

Acknowledgements. We thank the ship captains, the scientists, and funding agencies of all the projects (OUTPACE, BIOSOPE, MOORSPICE, DIAPALIS, NECTALIS, PANDORA, Mirai) that allowed data collection without which we could not validate our model. The authors thank the Institute of Research for Development for supporting all authors. Cyril Dutheil is funded by European project INTEGRE.

Edited by: Thierry Moutin

Reviewed by: Andreas Oschlies and one anonymous referee

\section{References}

Arrigo, K. R.: Marine microorganisms and global nutrient cycles, Nature, 437, 349-355, https://doi.org/10.1038/nature04159, 2005.

Assmann, K. M., Bentsen, M., Segschneider, J., and Heinze, C.: An isopycnic ocean carbon cycle model, Geosci. Model Dev., 3, 143-167, https://doi.org/10.5194/gmd-3-143-2010, 2010.

Aumont, O. and Bopp, L.: Globalizing results from ocean in situ iron fertilization studies: GLOBALIZING IRON FERTILIZATION, Global Biogeochem. Cy., 20, GB2017, https://doi.org/10.1029/2005GB002591, 2006.

Aumont, O., Ethé, C., Tagliabue, A., Bopp, L., and Gehlen, M.: PISCES-v2: an ocean biogeochemical model for carbon and ecosystem studies, Geosci. Model Dev., 8, 2465-2513, https://doi.org/10.5194/gmd-8-2465-2015, 2015.

Bennett, S. A., Achterberg, E. P., Connelly, D. P., Statham, P. J., Fones, G. R., and German, C. R.: The distribution and stabilisation of dissolved $\mathrm{Fe}$ in deep-sea hydrothermal plumes, Earth Planet. Sc. Lett., 270, 157-167, https://doi.org/10.1016/j.epsl.2008.01.048, 2008.

Bergman, B., Sandh, G., Lin, S., Larsson, J., and Carpenter, E. J.: Trichodesmium - a widespread marine cyanobacterium with unusual nitrogen fixation properties, FEMS Microbiol. Rev., 37, 286-302, https://doi.org/10.1111/j.1574-6976.2012.00352.x, 2013.

Berman-Frank, I.: Segregation of Nitrogen Fixation and Oxygenic Photosynthesis in the Marine Cyanobacterium Trichodesmium, Science, 294, 1534-1537, https://doi.org/10.1126/science.1064082, 2001.

Berthelot, H., Bonnet, S., Camps, M., Grosso, O., and Moutin, T.: Assessment of the dinitrogen released as ammonium and dis- solved organic nitrogen by unicellular and filamentous marine diazotrophic cyanobacteria grown in culture, Frontiers in Marine Science, 2, 80, https://doi.org/10.3389/fmars.2015.00080, 2015 a.

Berthelot, H., Moutin, T., L'Helguen, S., Leblanc, K., Hélias, S., Grosso, O., Leblond, N., Charrière, B., and Bonnet, S.: Dinitrogen fixation and dissolved organic nitrogen fueled primary production and particulate export during the VAHINE mesocosm experiment (New Caledonia lagoon), Biogeosciences, 12, 40994112, https://doi.org/10.5194/bg-12-4099-2015, 2015 b.

Berthelot, H., Bonnet, S., Grosso, O., Cornet, V., and Barani, A.: Transfer of diazotroph-derived nitrogen towards nondiazotrophic planktonic communities: a comparative study between Trichodesmium erythraeum, Crocosphaera watsonii and Cyanothece sp., Biogeosciences, 13, 4005-4021, https://doi.org/10.5194/bg-13-4005-2016, 2016.

Berthelot, H., Benavides, M., Moisander, P. H., Grosso, O., and Bonnet, S.: High-nitrogen fixation rates in the particulate and dissolved pools in the Western Tropical Pacific (Solomon and Bismarck Seas): $\mathrm{N}_{2}$ Fixation in the Western Pacific, Geophys. Res. Lett., 44, 8414-8423, https://doi.org/10.1002/2017GL073856, 2017.

Bissett, W., Walsh, J., Dieterle, D., and Carder, K.: Carbon cycling in the upper waters of the Sargasso Sea: I. Numerical simulation of differential carbon and nitrogen fluxes, Deep-Sea Res. Pt. I, 46, 205-269, https://doi.org/10.1016/S0967-0637(98)00062-4, 1999.

Bombar, D., Paerl, R. W., and Riemann, L.: Marine Non-Cyanobacterial Diazotrophs: Moving beyond Molecular Detection, Trends Microbiol., 24, 916-927, https://doi.org/10.1016/j.tim.2016.07.002, 2016.

Bonnet, S., Biegala, I. C., Dutrieux, P., Slemons, L. O., and Capone, D. G.: Nitrogen fixation in the western equatorial Pacific: Rates, diazotrophic cyanobacterial size class distribution, and biogeochemical significance: $\mathrm{N}_{2}$ fixation in the equatorial pacific, Global Biogeochem. Cy., 23, GB3012, https://doi.org/10.1029/2008GB003439, 2009.

Bonnet, S., Rodier, M., Turk-Kubo, K. A., Germineaud, C., Menkes, C., Ganachaud, A., Cravatte, S., Raimbault, P., Campbell, E., Quéroué, F., Sarthou, G., Desnues, A., Maes, C., and Eldin, G.: Contrasted geographical distribution of $\mathrm{N}_{2}$ fixation rates and nif $\mathrm{H}$ phylotypes in the Coral and Solomon Seas (southwestern Pacific) during austral winter conditions: $\mathrm{N}_{2}$ fixation and diversity in the pacific, Global Biogeochem. Cy., 29, 1874-1892, https://doi.org/10.1002/2015GB005117, 2015.

Bonnet, S., Berthelot, H., Turk-Kubo, K., Cornet-Barthaux, V., Fawcett, S., Berman-Frank, I., Barani, A., Grégori, G., Dekaezemacker, J., Benavides, M., and Capone, D. G.: Diazotroph derived nitrogen supports diatom growth in the South West Pacific: A quantitative study using nanoSIMS: Transfer of diazotrophic $\mathrm{N}$ into plankton, Limnol. Oceanogr., 61, 15491562, https://doi.org/10.1002/lno.10300, 2016a.

Bonnet, S., Berthelot, H., Turk-Kubo, K., Fawcett, S., Rahav, E., L'Helguen, S., and Berman-Frank, I.: Dynamics of $\mathrm{N}_{2}$ fixation and fate of diazotroph-derived nitrogen in a low-nutrient, low-chlorophyll ecosystem: results from the VAHINE mesocosm experiment (New Caledonia), Biogeosciences, 13, 2653-2673, https://doi.org/10.5194/bg-13-2653-2016, 2016 b. 
Bonnet, S., Caffin, M., Berthelot, H., and Moutin, T.: Hot spot of $\mathrm{N}_{2}$ fixation in the western tropical South Pacific pleads for a spatial decoupling between $\mathrm{N}_{2}$ fixation and denitrification, P. Natl. Acad. Sci. USA, 114, E2800-E2801, 2017.

Bonnet, S., Caffin, M., Berthelot, H., Grosso, O., Benavides, M., Helias-Nunige, S., Guieu, C., Stenegren, M., and Foster, R. A.: In-depth characterization of diazotroph activity across the western tropical South Pacific hotspot of $\mathrm{N}_{2}$ fixation (OUTPACE cruise), Biogeosciences, 15, 4215-4232, https://doi.org/10.5194/bg-15-4215-2018, 2018.

Breitbarth, E., Oschlies, A., and LaRoche, J.: Physiological constraints on the global distribution of Trichodesmium - effect of temperature on diazotrophy, Biogeosciences, 4, 53-61, https://doi.org/10.5194/bg-4-53-2007, 2007.

Breitbarth, E., Wohlers, J., Kläs, J., LaRoche, J., and Peeken, I.: Nitrogen fixation and growth rates of Trichodesmium IMS-101 as a function of light intensity, Mar. Ecol.-Prog. Ser., 359, 25-36, https://doi.org/10.3354/meps07241, 2008.

Böttjer, D., Dore, J. E., Karl, D. M., Letelier, R. M., Mahaffey, C., Wilson, S. T., Zehr, J., and Church, M. J.: Temporal variability of nitrogen fixation and particulate nitrogen export at Station ALOHA: Temporal variability of nitrogen fixation and particulate nitrogen, Limnol. Oceanogr., 62, 200-216, https://doi.org/10.1002/lno.10386, 2017.

Caffin, M., Moutin, T., Foster, R. A., Bouruet-Aubertot, P., Doglioli, A. M., Berthelot, H., Guieu, C., Grosso, O., Helias-Nunige, S., Leblond, N., Gimenez, A., Petrenko, A. A., de Verneil, A., and Bonnet, $\mathrm{S}$.: $\mathrm{N}_{2}$ fixation as a dominant new $\mathrm{N}$ source in the western tropical South Pacific Ocean (OUTPACE cruise), Biogeosciences, 15, 2565-2585, https://doi.org/10.5194/bg-152565-2018, 2018.

Capone, D. G.: Trichodesmium, a Globally Significant Marine Cyanobacterium, Science, 276, 1221-1229, https://doi.org/10.1126/science.276.5316.1221, 1997.

Carpenter, E. J.: Nitrogen Fixation by a Blue-Green Epiphyte on Pelagic Sargassum, Science, 178, 1207-1209, https://doi.org/10.1126/science.178.4066.1207, 1972.

Church, M. J., Jenkins, B. D., Karl, D. M., and Zehr, J. P.: Vertical distributions of nitrogen-fixing phylotypes at Stn ALOHA in the oligotrophic North Pacific Ocean, Aquat. Microb. Ecol., 38, 314, 2005.

Codispoti, L. A., Brandes, J. A., Christensen, J. P., Devol, A. H., Naqvi, S. A., Paerl, H. W., and Yoshinari, T.: The oceanic fixed nitrogen and nitrous oxide budgets: Moving targets as we enter the anthropocene?, Sci. Mar., 65, 85-105, https://doi.org/10.3989/scimar.2001.65s285, 2001.

Couvelard, X., Marchesiello, P., Gourdeau, L., and Lefèvre, J.: Barotropic Zonal Jets Induced by Islands in the Southwest Pacific, J. Phys. Oceanogr., 38, 2185-2204, https://doi.org/10.1175/2008JPO3903.1, 2008.

Cravatte, S., Madec, G., Izumo, T., Menkes, C., and Bozec, A.: Progress in the 3-D circulation of the eastern equatorial Pacific in a climate ocean model, Ocean Model., 17, 28-48, https://doi.org/10.1016/j.ocemod.2006.11.003, 2007.

Daines, S. J., Clark, J. R., and Lenton, T. M.: Multiple environmental controls on phytoplankton growth strategies determine adaptive responses of the $\mathrm{N}: \mathrm{P}$ ratio, Ecol. Lett., 17, 414-425, https://doi.org/10.1111/ele.12239, 2014.
Da Silva, A. M., Young, C., and Levitus, S.: Algorithms and Procedures, in: Atlas of Surface Marine Data, Vol. 1, p. 83, NOAA Atlas Nesdis Edn., US Department of Commerce, National Oceanographic Data Center, User Services Branch, Washington, D.C., 1994.

Delmont, T. O., Quince, C., Shaiber, A., Esen, O. C., Lee, S. T. M., Lucker, S., and Eren, A. M.: Nitrogen-fixing populations of Planctomycetes and Proteobacteria are abundant in surface ocean metagenomes, Nat. Microbiol., 3, 804-813, https://doi.org/10.1038/s41564-018-0176-9, 2018.

Deutsch, C., Gruber, N., Key, R. M., Sarmiento, J. L., and Ganachaud, A.: Denitrification and $\mathrm{N}_{2}$ fixation in the Pacific Ocean, Global Biogeochem. Cy., 15, 483-506, https://doi.org/10.1029/2000GB001291, 2001.

Deutsch, C., Sarmiento, J. L., Sigman, D. M., Gruber, N., and Dunne, J. P.: Spatial coupling of nitrogen inputs and losses in the ocean, Nature, 445, 163-167, https://doi.org/10.1038/nature05392, 2007.

Dunne, J. P., John, J. G., Shevliakova, E., Stouffer, R. J., Krasting, J. P., Malyshev, S. L., Milly, P. C. D., Sentman, L. T., Adcroft, A. J., Cooke, W., Dunne, K. A., Griffies, S. M., Hallberg, R. W., Harrison, M. J., Levy, H., Wittenberg, A. T., Phillips, P. J., and Zadeh, N.: GFDL-ESM2 Global Coupled Climate-Carbon Earth System Models. Part II: Carbon System Formulation and Baseline Simulation Characteristics, J. Climate, 26, 2247-2267, https://doi.org/10.1175/JCLI-D-12-00150.1, 2013.

Dupouy, C., Neveux, J., Subramaniam, A., Mulholland, M. R., Montoya, J. P., Campbell, L., Carpenter, E. J., and Capone, D. G.: Satellite captures trichodesmium blooms in the southwestern tropical Pacific, Eos T. Am. Geophys. Un., 81, 13-16, https://doi.org/10.1029/00EO00008, 2000.

Dupouy, C., Benielli-Gary, D., Neveux, J., Dandonneau, Y., and Westberry, T. K.: An algorithm for detecting Trichodesmium surface blooms in the South Western Tropical Pacific, Biogeosciences, 8, 3631-3647, https://doi.org/10.5194/bg-8-36312011, 2011.

Dutkiewicz, S., Ward, B. A., Monteiro, F., and Follows, M. J.: Interconnection of nitrogen fixers and iron in the Pacific Ocean: Theory and numerical simulations: marine nitrogen fixers and iron, Global Biogeochem. Cy., 26, GB1012, https://doi.org/10.1029/2011GB004039, 2012.

Falcón, L. I., Pluvinage, S., and Carpenter, E. J.: Growth kinetics of marine unicellular $\mathrm{N}$-fixing cyanobacterial isolates in continuous culture in relation to phosphorus and temperature, Mar. Ecol.Prog. Ser., 285, 3-9, 2005.

Fennel, K., Spitz, Y. H., Letelier, R. M., Abbott, M. R., and Karl, D. M.: A deterministic model for $\mathrm{N}_{2}$ fixation at stn. ALOHA in the subtropical North Pacific Ocean, Deep-Sea Res. Pt. II, 49, 149-174, 2001.

Flynn, K. J. and Hipkin, C. R.: INTERACTIONS BETWEEN IRON, LIGHT, AMMONIUM, AND NITRATE: INSIGHTS FROM THE CONSTRUCTION OF A DYNAMIC MODEL OF ALGAL PHYSIOLOGY, J. Phycol., 35, 1171-1190, https://doi.org/10.1046/j.1529-8817.1999.3561171.x, 1999.

Flynn, K. J., Fasham, M. J., and Hipkin, C. R.: Modelling the interactions between ammonium and nitrate uptake in marine phytoplankton, Philos. T. Roy. Soc. B, 352, 1625-1645, 1997. 
Gallon, J. R.: Reconciling the incompatible: $\mathrm{N}_{2}$ fixation And $\mathrm{O}_{2}$, New Phytol., 122, 571-609, https://doi.org/10.1111/j.14698137.1992.tb00087.x, 1992.

Galloway, J. N., Dentener, F. J., Capone, D. G., Boyer, E. W., Howarth, R. W., Seitzinger, S. P., Asner, G. P., Cleveland, C. C., Green, P. A., Holland, E. A., Karl, D. M., Michaels, A. F., Porter, J. H., Townsend, A. R., and Vörösmarty, C. J.: Nitrogen Cycles: Past, Present, and Future, Biogeochemistry, 70, 153-226, https://doi.org/10.1007/s10533-004-0370-0, 2004.

Garcia, N., Raimbault, P., and Sandroni, V.: Seasonal nitrogen fixation and primary production in the Southwest Pacific: nanoplankton diazotrophy and transfer of nitrogen to picoplankton organisms, Mar. Ecol.-Prog. Ser., 343, 25-33, https://doi.org/10.3354/meps06882, 2007.

Goebel, N. L., Edwards, C. A., Carter, B. J., Achilles, K. M., and Zehr, J. P.: Growth and carbon content of three different-sized diazotrophic cyanobacteria observed in the subtropical north pacific, J. Phycol., 44, 1212-1220, https://doi.org/10.1111/j.15298817.2008.00581.x, 2008.

Großkopf, T., Mohr, W., Baustian, T., Schunck, H., Gill, D., Kuypers, M. M. M., Lavik, G., Schmitz, R. A., Wallace, D. W. R., and LaRoche, J.: Doubling of marine dinitrogen-fixation rates based on direct measurements, Nature, 488, 361-364, https://doi.org/10.1038/nature11338, 2012.

Gruber, N.: Oceanography: A bigger nitrogen fix, Nature, 436, 786787, 2005

Gruber, N.: The Marine Nitrogen Cycle: Overview and challenges, in: Nitrogen in the Marine Environment, 1-50, Elsevier, https://doi.org/10.1016/B978-0-12-372522-6.00001-3, 2008.

Guieu, C., Bonnet, S., Petrenko, A., Menkes, C., Chavagnac, V., Desboeufs, K., Maes, C., and Moutin, T.: Iron from a submarine source impacts the productive layer of the Western Tropical South Pacific (WTSP), Sci. Rep.-UK, 8, 9075, https://doi.org/10.1038/s41598-018-27407-z, 2018.

Halm, H., Lam, P., Ferdelman, T. G., Lavik, G., Dittmar, T., LaRoche, J., D'Hondt, S., and Kuypers, M. M.: Heterotrophic organisms dominate nitrogen fixation in the South Pacific Gyre, ISME J., 6, 1238-1249, https://doi.org/10.1038/ismej.2011.182, 2012.

Hawser, S. P., O’Neil, J. M., Roman, M. R., and Codd, G. A.: Toxicity of blooms of the cyanobacterium Trichodesmium to zooplankton, J. Appl. Phycol., 4, 79-86, 1992.

Hood, R. R., Bates, N. R., Capone, D. G., and Olson, D. B.: Modeling the effect of nitrogen fixation on carbon and nitrogen fluxes at BATS, Deep-Sea Res. Pt. II, 48, 1609-1648, https://doi.org/10.1016/S0967-0645(00)00160-0, 2001.

Johnson, K. S., Chavez, F. P., and Friederich, G. E.: Continentalshelf sediment as a primary source of iron for coastal phytoplankton, Nature, 398, 697-700, https://doi.org/10.1038/19511, 1999.

Jullien, S., Menkes, C. E., Marchesiello, P., Jourdain, N. C., Lengaigne, M., Koch-Larrouy, A., Lefèvre, J., Vincent, E. M., and Faure, V.: Impact of Tropical Cyclones on the Heat Budget of the South Pacific Ocean, J. Phys. Oceanogr., 42, 1882-1906, https://doi.org/10.1175/JPO-D-11-0133.1, 2012.

Jullien, S., Marchesiello, P., Menkes, C. E., Lefèvre, J., Jourdain, N. C., Samson, G., and Lengaigne, M.: Ocean feedback to tropical cyclones: climatology and processes, Clim. Dynam., 43, 2831-2854, https://doi.org/10.1007/s00382-014-2096-6, 2014.
Karl, D., Letelier, R., Tupas, L., Dore, J., Christian, J., and Hebel, D.: The role of nitrogen fixation in biogeochemical cycling in the subtropical North Pacific Ocean, Nature, 388, 533-538, 1997.

Kessler, W. S. and Gourdeau, L.: The Annual Cycle of Circulation of the Southwest Subtropical Pacific, Analyzed in an Ocean GCM*, J. Phys. Oceanogr., 37, 1610-1627, https://doi.org/10.1175/JPO3046.1, 2007.

Klausmeier, C. A., Litchman, E., Daufresne, T., and Levin, S. A.: Optimal nitrogen-to-phosphorus stoichiometry of phytoplankton, Nature, 429, 171-174, https://doi.org/10.1038/nature02454, 2004.

Krishnamurthy, A., Moore, J. K., Mahowald, N., Luo, C., Doney, S. C., Lindsay, K., and Zender, C. S.: Impacts of increasing anthropogenic soluble iron and nitrogen deposition on ocean biogeochemistry: atmospheric $\mathrm{Fe}$ and $\mathrm{N}$ and ocean biogoechemistry, Global Biogeochem. Cy., 23, GB3016, https://doi.org/10.1029/2008GB003440, 2009.

Kromkamp, J. and Walsby, A. E.: Buoyancy Regulation and Vertical Migration of Trichodesmium: a Computer-Model Prediction, in: Marine Pelagic Cyanobacteria: Trichodesmium and other Diazotrophs, edited by: Carpenter, E. J., Capone, D. G., and Rueter, J. G., 239-248, Springer Netherlands, Dordrecht, https://doi.org/10.1007/978-94-015-7977-3_15, 1992.

Kustka, A. B., Sanudo-Wilhelmy, S. A., Carpenter, E. J., Capone, D., Burns, J., and Sunda, W. G.: Iron requirements for dinitrogenand ammonium-supported growth in cultures of Trichodesmium (IMS 101): Comparison with nitrogen fixation rates and iron: carbon ratios of field populations, Limnol. Oceanogr., 48, 18691884, 2003.

Kwiatkowski, L., Aumont, O., Bopp, L., and Ciais, P.: The Impact of Variable Phytoplankton Stoichiometry on Projections of Primary Production, Food Quality, and Carbon Uptake in the Global Ocean, Global Biogeochem. Cy., 32, 516-528, https://doi.org/10.1002/2017GB005799, 2018.

Küpper, H., etlk, I., Seibert, S., Pril, O., Etlikova, E., Strittmatter, M., Levitan, O., Lohscheider, J., Adamska, I., and BermanFrank, I.: Iron limitation in the marine cyanobacterium Trichodesmium reveals new insights into regulation of photosynthesis and nitrogen fixation, New Phytol., 179, 784-798, https://doi.org/10.1111/j.1469-8137.2008.02497.x, 2008.

Large, W. G., McWilliams, J. C., and Doney, S. C.: Oceanic vertical mixing: A review and a model with a nonlocal boundary layer parameterization, Rev. Geophys., 32, 363, https://doi.org/10.1029/94RG01872, 1994.

LaRoche, J. and Breitbarth, E.: Importance of the diazotrophs as a source of new nitrogen in the ocean, J. Sea Res., 53, 67-91, https://doi.org/10.1016/j.seares.2004.05.005, 2005.

Letelier, R. and Karl, D.: Trichodesmium spp. physiology and nutrient fluxes in the North Pacific subtropical gyre, Aquat. Microb. Ecol., 15, 265-276, https://doi.org/10.3354/ame015265, 1998.

Luo, Y.-W., Doney, S. C., Anderson, L. A., Benavides, M., BermanFrank, I., Bode, A., Bonnet, S., Boström, K. H., Böttjer, D., Capone, D. G., Carpenter, E. J., Chen, Y. L., Church, M. J., Dore, J. E., Falcón, L. I., Fernández, A., Foster, R. A., Furuya, K., Gómez, F., Gundersen, K., Hynes, A. M., Karl, D. M., Kitajima, S., Langlois, R. J., LaRoche, J., Letelier, R. M., Marañón, E., McGillicuddy Jr., D. J., Moisander, P. H., Moore, C. M., Mouriño-Carballido, B., Mulholland, M. R., Needoba, J. A., Orcutt, K. M., Poulton, A. J., Rahav, E., Raimbault, P., Rees, 
A. P., Riemann, L., Shiozaki, T., Subramaniam, A., Tyrrell, T., Turk-Kubo, K. A., Varela, M., Villareal, T. A., Webb, E. A., White, A. E., Wu, J., and Zehr, J. P.: Database of diazotrophs in global ocean: abundance, biomass and nitrogen fixation rates, Earth Syst. Sci. Data, 4, 47-73, https://doi.org/10.5194/essd-447-2012, 2012.

Luo, Y.-W., Lima, I. D., Karl, D. M., Deutsch, C. A., and Doney, S. C.: Data-based assessment of environmental controls on global marine nitrogen fixation, Biogeosciences, 11, 691-708, https://doi.org/10.5194/bg-11-691-2014, 2014.

Maier-Reimer, E., Kriest, I., Segschneider, J., and Wetzel, P.: The Hamburg Ocean Carbon Cycle Model HAMOCC5 - Technical Description Release 1.1, Reports on earth system science, 14, available at: http://eprints.uni-kiel.de/14321/1/erdsystem_14.pdf (last access: 12 July 2018), 2005.

Marchesiello, P., McWilliams, J. C., and Shchepetkin, A.: Open boundary conditions for long-term integration of regional oceanic models, Ocean Model., 3, 1-20, https://doi.org/10.1016/S1463-5003(00)00013-5, 2001.

Marchesiello, P., Lefèvre, J., Vega, A., Couvelard, X., and Menkes, C.: Coastal upwelling, circulation and heat balance around New Caledonia's barrier reef, Mar. Pollut. Bull., 61, 432-448, https://doi.org/10.1016/j.marpolbul.2010.06.043, 2010.

Meunier, C. L., Malzahn, A. M., and Boersma, M.: A New Approach to Homeostatic Regulation: Towards a Unified View of Physiological and Ecological Concepts, PLoS ONE, 9, e107737, https://doi.org/10.1371/journal.pone.0107737, 2014.

Mills, M. M., Ridame, C., Davey, M., La Roche, J., and Geider, R. J.: Iron and phosphorus co-limit nitrogen fixation in the eastern tropical North Atlantic, Nature, 429, 292-294, 2004.

Mohr, W., Großkopf, T., Wallace, D. W. R., and LaRoche, J.: Methodological Underestimation of Oceanic Nitrogen Fixation Rates, PLoS ONE, 5, e12583, https://doi.org/10.1371/journal.pone.0012583, 2010.

Moisander, P. H., Beinart, R. A., Voss, M., and Zehr, J. P.: Diversity and abundance of diazotrophic microorganisms in the South China Sea during intermonsoon, ISME J., 2, 954-967, 2008.

Moisander, P. H., Beinart, R. A., Hewson, I., White, A. E., Johnson, K. S., Carlson, C. A., Montoya, J. P., and Zehr, J. P.: Unicellular cyanobacterial distributions broaden the oceanic $\mathrm{N}_{2}$ fixation domain, Science, 327, 1512-1514, 2010.

Moisander, P. H., Benavides, M., Bonnet, S., Berman-Frank, I., White, A. E., and Riemann, L.: Chasing after Non-cyanobacterial Nitrogen Fixation in Marine Pelagic Environments, Front. Microbiol., 8, 1736, https://doi.org/10.3389/fmicb.2017.01736, 2017.

Monteiro, F. M., Dutkiewicz, S., and Follows, M. J.: Biogeographical controls on the marine nitrogen fixers: controls on marine nitrogen fixers, Global Biogeochem. Cy., 25, GB2003, https://doi.org/10.1029/2010GB003902, 2011.

Montoya, J. P., Holl, C. M., Zehr, J. P., Hansen, A., Villareal, T. A., and Capone, D. G.: High rates of $\mathrm{N}_{2}$ fixation by unicellular diazotrophs in the oligotrophic Pacific Ocean, Nature, 430, 10271032, https://doi.org/10.1038/nature02824, 2004.

Moore, C. M., Mills, M. M., Arrigo, K. R., Berman-Frank, I., Bopp, L., Boyd, P. W., Galbraith, E. D., Geider, R. J., Guieu, C., Jaccard, S. L., Jickells, T. D., La Roche, J., Lenton, T. M., Mahowald, N. M., Marañón, E., Marinov, I., Moore, J. K., Nakatsuka, T., Oschlies, A., Saito, M. A.,
Thingstad, T. F., Tsuda, A., and Ulloa, O.: Processes and patterns of oceanic nutrient limitation, Nat. Geosci., 6, 701-710, https://doi.org/10.1038/ngeo1765, 2013.

Moore, J. K., Doney, S. C., Kleypas, J. A., Glover, D. M., and Fung, I. Y.: An intermediate complexity marine ecosystem model for the global domain, Deep-Sea Res. Pt. II, 49, 403-462, 2001.

Moore, J. K., Doney, S. C., and Lindsay, K.: Upper ocean ecosystem dynamics and iron cycling in a global three-dimensional model: global ecosystem-biogeochemical model, Global Biogeochem. Cy., 18, GB4028, https://doi.org/10.1029/2004GB002220, 2004.

Moore, J. K., Doney, S. C., Lindsay, K., Mahowald, N., and Michaels, A. F.: Nitrogen fixation amplifies the ocean biogeochemical response to decadal timescale variations in mineral dust deposition, Tellus B, 58, 560-572, https://doi.org/10.1111/j.1600-0889.2006.00209.x, 2006.

Moutin, T., Van Den Broeck, N., Beker, B., Dupouy, C., Rimmelin, P., and Le Bouteiller, A.: Phosphate availability controls Trichodesmium spp. biomass in the SW Pacific Ocean, Mar. Ecol.Prog. Ser., 297, 15-21, 2005.

Moutin, T., Karl, D. M., Duhamel, S., Rimmelin, P., Raimbault, P., Van Mooy, B. A. S., and Claustre, H.: Phosphate availability and the ultimate control of new nitrogen input by nitrogen fixation in the tropical Pacific Ocean, Biogeosciences, 5, 95-109, https://doi.org/10.5194/bg-5-95-2008, 2008.

Mulholland, M. R. and Capone, D. G.: The nitrogen physiology of the marine $\mathrm{N}_{2}$-fixing cyanobacteria Trichodesmium spp. Trends Plant Sci., 5, 148-153, https://doi.org/10.1016/S13601385(00)01576-4, 2000.

Mulholland, M. R. and Capone, D. G.: Stoichiometry of nitrogen and carbon utilization in cultured populations of Trichodesmium IMS101: Implications for growth, Limnol. Oceanogr., 46, 436443, 2001.

Mulholland, M. R., Ohki, K., and Capone, D. G.: Nutrient controls on nitrogen uptake and metabolism by natural populations and cultures of Trichodesmium (cyanobacteria), J. Phycol., 37, 10011009, https://doi.org/10.1046/j.1529-8817.2001.00080.x, 2001.

Neveux, J., Tenírio, M. M. B., Dupouy, C., and Villareal, T. A.: Spectral diversity of phycoerythrins and diazotroph abundance in tropical waters, Limnol. Oceanogr., 51, 1689-1698, https://doi.org/10.4319/lo.2006.51.4.1689, 2006.

Ohki, K., Zehr, J. P., and Fujita, Y.: Regulation of nitrogenase activity in relation to the light-dark regime in the filamentous nonheterocystous cyanobacterium Trichodesmium sp. NIBB 1067, Microbiology, 138, 2679-2685, 1992.

O'Neil, J. and Romane, M.: Grazers and Associated Organisms of Trichodesmium, in: Marine Pelagic Cyanobacteria: Trichodesmium and other Diazotrophs, Vol. 362, Springer Netherlands, Dordrecht, 1992.

Paerl, H. W., Priscu, J. C., and Brawner, D. L.: Immunochemical localization of nitrogenase in marine Trichodesmium aggregates: Relationship to $\mathrm{N}_{2}$ fixation potential, Appl. Environ. Microbiol., 55, 2965-2975, 1989.

Pahlow, M. and Oschlies, A.: Chain model of phytoplankton P, $\mathrm{N}$ and light colimitation, Mar. Ecol.-Prog. Ser., 376, 69-83, https://doi.org/10.3354/meps07748, 2009.

Penven, P., Debreu, L., Marchesiello, P., and McWilliams, J. C.: Evaluation and application of the ROMS 1-way embedding procedure to the central california upwelling system, Ocean Model., 
12, 157-187, https://doi.org/10.1016/j.ocemod.2005.05.002, 2006.

Postgate, J. R.: Biology nitrogen fixation: fundamentals, Philos. T. Roy. Soc. B, 296, 375-385, 1982.

Radic, A., Lacan, F., and Murray, J. W.: Iron isotopes in the seawater of the equatorial Pacific Ocean: New constraints for the oceanic iron cycle, Earth Planet. Sc. Lett., 306, 1-10, https://doi.org/10.1016/j.epsl.2011.03.015, 2011.

Raimbault, P. and Garcia, N.: Evidence for efficient regenerated production and dinitrogen fixation in nitrogen-deficient waters of the South Pacific Ocean: impact on new and export production estimates, Biogeosciences, 5, 323-338, https://doi.org/10.5194/bg-5-323-2008, 2008.

Ramamurthy, V. D. and Krishnamurthy, S.: Effects of N : P ratios on the uptake of nitrate and phosphate by laboratory cultures of Trichodesmium erythraeum (Ehr.), Proceedings: Plant Sciences, 65, 43-48, 1967.

Raven, J. A.: The iron and molybdenum use efficiencies of plant growth with different energy, carbon and nitrogen sources, New Phytol., 109, 279-287, https://doi.org/10.1111/j.14698137.1988.tb04196.x, 1988.

Rubin, M., Berman-Frank, I., and Shaked, Y.: Dust- and mineraliron utilization by the marine dinitrogen-fixer Trichodesmium, Nat. Geosci., 4, 529-534, https://doi.org/10.1038/ngeo1181, 2011.

Rueter, J. G.: Iron stimulation of photosynthesis and nitrogen fixation in Anabaena 7120 and Trichodesmium (Cyanophyceae), J. Phycol., 24, 249-254, https://doi.org/10.1111/j.15298817.1988.tb04240.x, 1988.

Shchepetkin, A. F. and McWilliams, J. C.: The regional oceanic modeling system (ROMS): a split-explicit, free-surface, topography-following-coordinate oceanic model, Ocean Model., 9, 347-404, https://doi.org/10.1016/j.ocemod.2004.08.002, 2005.

Shiozaki, T., Kodama, T., Kitajima, S., Sato, M., and Furuya, K.: Advective transport of diazotrophs and importance of their nitrogen fixation on new and primary production in the western Pacific warm pool, Limnol. Oceanogr., 58, 49-60, https://doi.org/10.4319/lo.2013.58.1.0049, 2013.

Shiozaki, T., Kodama, T., and Furuya, K.: Large-scale impact of the island mass effect through nitrogen fixation in the western South Pacific Ocean: island mass effect through $\mathrm{N}_{2}$ fixation, Geophys. Res. Lett., 41, 2907-2913, https://doi.org/10.1002/2014GL059835, 2014.

Shiozaki, T., Nagata, T., Ijichi, M., and Furuya, K.: Nitrogen fixation and the diazotroph community in the temperate coastal region of the northwestern North Pacific, Biogeosciences, 12, 4751-4764, https://doi.org/10.5194/bg-12-4751-2015, 2015.

Staal, M., Meysman, F. J. R., and Stal, L. J.: Temperature excludes $\mathrm{N}_{2}$-fixing heterocystous cyanobacteria in the tropical oceans, Nature, 425, 501-504, https://doi.org/10.1038/nature02001, 2003.

Stenegren, M., Caputo, A., Berg, C., Bonnet, S., and Foster, R. A.: Distribution and drivers of symbiotic and free-living diazotrophic cyanobacteria in the western tropical South Pacific, Biogeosciences, 15, 1559-1578, https://doi.org/10.5194/bg-151559-2018, 2018.

Sterner, R. W. and Elser, J. J.: Ecological Stoichiometry: The Biology of Elements from Molecules to the Biosphere, https://doi.org/10.1515/9781400885695, 2002.
Sunda, W. G. and Huntsman, S. A.: Interrelated influence of iron, light and cell size on marine phytoplankton growth, Nature, 390, 389-392, https://doi.org/10.1038/37093, 1997.

Tagliabue, A., Bopp, L., and Aumont, O.: Ocean biogeochemistry exhibits contrasting responses to a large scale reduction in dust deposition, Biogeosciences, 5, 11-24, https://doi.org/10.5194/bg-5-11-2008, 2008.

Tagliabue, A., Bopp, L., Dutay, J.-C., Bowie, A. R., Chever, F., Jean-Baptiste, P., Bucciarelli, E., Lannuzel, D., Remenyi, T., Sarthou, G., Aumont, O., Gehlen, M., and Jeandel, C.: Hydrothermal contribution to the oceanic dissolved iron inventory, Nat. Geosci., 3, 252-256, https://doi.org/10.1038/ngeo818, 2010.

Tagliabue, A., Mtshali, T., Aumont, O., Bowie, A. R., Klunder, M. B., Roychoudhury, A. N., and Swart, S.: A global compilation of dissolved iron measurements: focus on distributions and processes in the Southern Ocean, Biogeosciences, 9, 2333-2349, https://doi.org/10.5194/bg-9-2333-2012, 2012.

Tegen, I. and Fung, I.: Contribution to the atmospheric mineral aerosol load from land surface modification, J. Geophys. Res., 100, 18707, https://doi.org/10.1029/95JD02051, 1995.

Toner, B. M., Fakra, S. C., Manganini, S. J., Santelli, C. M., Marcus, M. A., Moffett, J. W., Rouxel, O., German, C. R., and Edwards, K. J.: Preservation of iron(II) by carbon-rich matrices in a hydrothermal plume, Nat. Geosci., 2, 197-201, https://doi.org/10.1038/ngeo433, 2009.

Turk-Kubo, K. A., Karamchandani, M., Capone, D. G., and Zehr, J. P.: The paradox of marine heterotrophic nitrogen fixation: abundances of heterotrophic diazotrophs do not account for nitrogen fixation rates in the Eastern Tropical South Pacific: $\mathrm{N}_{2}$ fixing potential of heterotrophs in the ETSP, Environ. Microbiol., 16, 3095-3114, https://doi.org/10.1111/1462-2920.12346, 2014.

Villareal, T. and Carpenter, E.: Buoyancy Regulation and the Potential for Vertical Migration in the Oceanic Cyanobacterium Trichodesmium, Microb. Ecol., 45, 1-10, https://doi.org/10.1007/s00248-002-1012-5, 2003.

Villareal, T. A. and Carpenter, E. J.: Diel buoyancy regulation in the marine diazotrophic cyanobacterium Trichodesmium thiebautii, Limnol. Oceanogr., 35, 1832-1837, https://doi.org/10.4319/lo.1990.35.8.1832, 1990.

White, A., Spitz, Y., and Letelier, R.: Modeling carbohydrate ballasting by Trichodesmium spp., Mar. Ecol.-Prog. Ser., 323, 3545, https://doi.org/10.3354/meps323035, 2006.

Ye, Y., Völker, C., Bracher, A., Taylor, B., and Wolf-Gladrow, D. A.: Environmental controls on $\mathrm{N}_{2}$ fixation by Trichodesmium in the tropical eastern North Atlantic Ocean A model-based study, Deep-Sea Res. Pt. I, 64, 104-117, https://doi.org/10.1016/j.dsr.2012.01.004, 2012.

Zahariev, K., Christian, J. R., and Denman, K. L.: Preindustrial, historical, and fertilization simulations using a global ocean carbon model with new parameterizations of iron limitation, calcification, and $\mathrm{N}_{2}$ fixation, Prog. Oceanogr., 77, 56-82, https://doi.org/10.1016/j.pocean.2008.01.007, 2008.

Zehr, J. P. and Bombar, D.: Marine Nitrogen Fixation: Organisms, Significance, Enigmas, and Future Directions, in: Biological Nitrogen Fixation, edited by: de Bruijn, F. J., 855-872, John Wiley \& Sons, Inc., Hoboken, NJ, USA, https://doi.org/10.1002/9781119053095.ch84, 2015. 